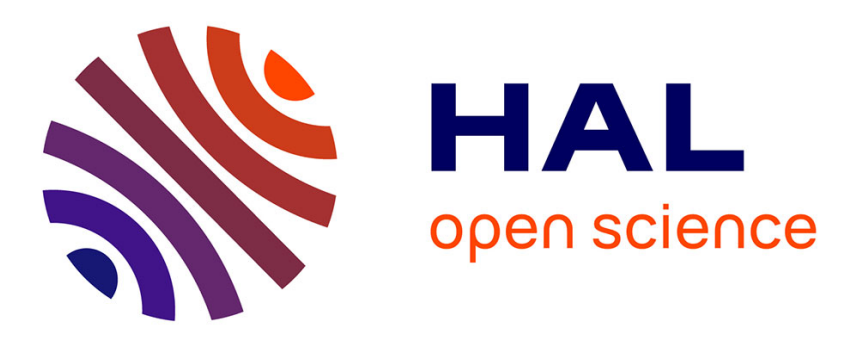

\title{
Transient presence of a teiid lizard in the European Eocene suggests transatlantic dispersal and rapid extinction
}

\author{
Marc Louis Augé, Brizuela Santiago
}

\section{- To cite this version:}

Marc Louis Augé, Brizuela Santiago. Transient presence of a teiid lizard in the European Eocene suggests transatlantic dispersal and rapid extinction. Palaeobiodiversity and Palaeoenvironments, 2020, 10.1007/s12549-019-00414-2 . hal-02550635

\section{HAL Id: hal-02550635 \\ https://hal.sorbonne-universite.fr/hal-02550635}

Submitted on 22 Apr 2020

HAL is a multi-disciplinary open access archive for the deposit and dissemination of scientific research documents, whether they are published or not. The documents may come from teaching and research institutions in France or abroad, or from public or private research centers.
L'archive ouverte pluridisciplinaire HAL, est destinée au dépôt et à la diffusion de documents scientifiques de niveau recherche, publiés ou non, émanant des établissements d'enseignement et de recherche français ou étrangers, des laboratoires publics ou privés. 


\title{
Transient presence of a teiid lizard in the European Eocene suggests transatlantic dispersal and rapid extinction
}

\author{
Augé Marc Louis ${ }^{1}$ (D) Brizuela Santiago $^{2}$
}

\begin{abstract}
Several teiid specimens (frontal, vertebra, maxillae) are described from the late Eocene of Europe (MP17, Phosphorites du Quercy). The results of phylogenetic analyses confirm that these European Eocene fossils belong to teiid lizards and more specifically to the subfamily Tupinambinae. So far, the Paleogene record of teiids is limited to South America and no occurrence of crown teiids is known in Europe. This disjunct distribution of teiids during the Eocene suggests transatlantic dispersal and this possibility is discussed. The presence of teiids in the European fossil record is brief (limited to standard level MP17). The circumstances that prevented the persistence of an invading clade in Europe are examined. Ecological (e.g. biotic interactions) and/or demographic (Allee effect) processes may have been involved.
\end{abstract}

Keywords Teiid lizards $\cdot$ Eocene $\cdot$ Europe $\cdot$ Dispersal $\cdot$ Extinction debt

\section{Introduction}

Extant teiids are a New World lizard family, widely distributed in South and Central America and the West Indies with a single native genus in North America (Brizuela and Albino 2004). They are active, diurnal lizards and sometimes considered as the ecological counterparts of Old World lacertid lizards (Pianka and Vitt 2003).

The Cenozoic fossil record of Teiidae (sensu Nydam et al. 2007) is nearly limited to South America (Quadros et al. 2018). The earliest records of teiids are from the early Paleogene of Brazil and Argentina (Carvalho 2001; Brizuela and Albino

Augé Marc Louis

marc.louis.ed.auge@gmail.com

Brizuela Santiago

brizuela@mdp.edu.ar

1 Muséum national d'Histoire naturelle, CR2P, UMR 7207 CNRS, MNHN, Université Paris 6, CP 38, 57 rue Cuvier, Cedex 05, 75231 Paris, France

2 Departamento de Biologia Facultad de Ciencias Exactas y Naturales, Consejo Nacional de Investigationes Científicas y Técnicas (CONICET), Universidad Nacional de Mar del Plata, Consejo, Funes 3250, B7602AYJ Mar del Plata, Argentina
2016). These records are of tupinambine teiids indicating that the family had already differentiated in the two main lineages before the Paleocene-Eocene boundary. The origin of the family would be therefore older (Cretaceous-Paleocene) as also inferred by molecular data (Giugliano et al. 2007). Recently, a Late Cretaceous European radiation of lizards, i.e. Barbatteiidae, has been recognised (Venczel and Codrea 2016; Codrea et al. 2017) and is considered as sister to Teiidae, further sustaining the early origin of the Teiidae. As far as we know, outside South America, teiid lizards have only been reported from the Neogene of North America and the Caribbean with their earliest presence (Cnemidophorinae) in the lower Miocene of Florida (Estes 1983).

A purported teiid lizard has already been described in the European Eocene (Augé 2005), but there are some apparently significant morphological differences between this taxon and modern teiids (Brizuela 2010). Here, we report the presence of a teiid lizard in the European late Eocene. An azygous frontal from the locality of La Bouffie (European Standard Mammalian level MP 17, Phosphorites du Quercy, France, Fig. 1) is nearly identical to frontals of extant teiid lizards. Moreover, one trunk vertebra and two fragmentary maxillae from coeval localities in the Phosphorites du Quercy (late Eocene, MP17) show distinct teiid morphology.

The family Teiidae (sensu stricto) has no known Paleocene or early Eocene record in Europe. Barbatteiidae are present in the late European Mesozoic but a phylogenetic analysis including the fossils studied here indicates that these fossils were of crown 

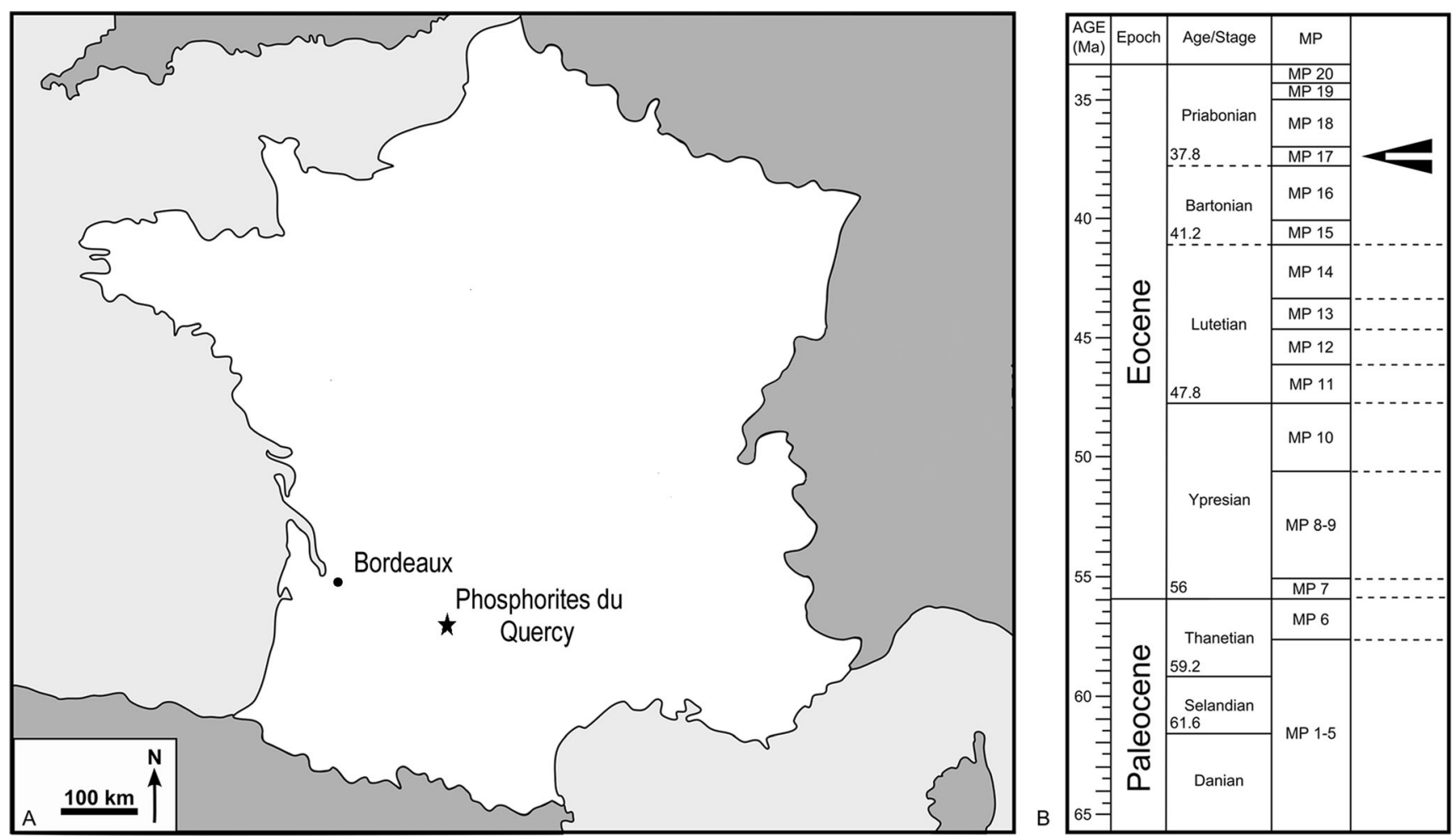

Fig. 1 Geographical and stratigraphic setting of Eocene teiids in Europe. a Map showing the geographical location of the Phosphorites du Quercy (France). b Stratigraphic chart of the early Paleogene, showing the age (MP17) of the localities that have yielded teiids remains

teiids. Therefore, independent evolution of the European forms is unlikely, for lack of suitable local ancestors.

The disjunct distribution of teiid lizards during the Eocene (South America and Europe) deserves some explanations. Most taxa have undergone significant shifts in their geographic range and these movements of species between distinct biotas often follow the physical removal of barriers between them (e.g. The Great American Interchange (Marshall et al. 1982; Stehli and Webbs 1985, Webb 1991). Exceptions to these generalisations are known and there are compelling evidence that some vertebrates (lizards and land mammals) crossed the Atlantic during the Paleogene probably by rafting (Vermeij 2005). The possibility of transatlantic dispersal involving teiid lizards during the late Eocene is discussed below.

The vertebrate fossil record chronicles many episodes of dispersal and biotic interchanges. These are common and important biogeographic phenomenon (Vermeij 2005). Present biological invasions provide evidence that species disperse to places where those species did not originate (e.g. Simpson 1940; Mooney and Cleland 2001). The study of past dispersals or invasions in the history of life offers opportunities to examine the long term consequences of biological exchanges and in particular the fate of newcomers in the recipient biota. On an evolutionary time scale, the persistence of the new established species depends mostly on conditions encountered in the recipient biota. The presence of teiid lizards in the European fossil record is brief (MP17, early late
Eocene) so, this event opens an opportunity to examine the circumstances that apparently prevented the persistence and diversification of an invading clade.

\section{Geological setting}

Specimens described here were recovered from three localities within the Phosphorites du Quercy (southwestern France) which comprises numerous fissures and cavities dissolved out of the ancient limestone bedrock during the Eocene and the Oligocene. These fissures accumulated phosphatic sediments that produced rich vertebrate faunas. Over the last few decades, a time sequence for these localities and their fossils was determined. The age of the most productive localities ranges from the late middle Eocene (MP16, late Bartonian) to the late Oligocene (MP28, Chattian) (Gèze 1938; SchmidtKittler 1987; Rage 2006). The three localities that yielded teiid lizards were assigned a MP17 (late Eocene) age.

\section{Material and methods}

The fossils studied here are deposited in the Muséum national d'Histoire naturelle, Paris, France (Institutional Abbreviation: MNHN). 
The morphological datasets for the phylogenetic analyses were assembled in Nexus format (see matrices in appendices 1, 2 and 3, character list in appendices 4 and 5). The matrices were analysed by parsimony method, using the traditional search, tree bisection reconnection option in the program TNT Version 1.1, December 2007 (Goloboff et al. 2008). Consensus trees were edited with the program Mesquite, version 3.04 (Maddison and Maddison 2016). A separate analysis was conducted using the New Technology Search in TNT. Bremer Support values were also generated by the New Technology Search program.

Here, we perform three analyses of morphological data. The first analysis is limited to characters related to the vertebral column, and it includes 21 vertebral characters coded in 24 extant and two fossil taxa (the varanid genus Saniwa and the purported teiid vertebra described above) with the outgroup genus Sphenodon (see characters and discussion in Augé and Guével 2018). The extant taxa are taken from species belonging to the main lizard groups: Gekkota, Cordylidae, Scincidae, Lacertidae, Teiidae, Iguania (Iguanidae s.l. and Agamidae), Anguimorpha (Anguidae, Xenosaurus, Heloderma, Varanidae sensu Estes et al. 1988, see details in Augé and Guével 2018). An important lizard taxon, the Amphisbaenia, has not been included in this analysis. False phylogenetic signals associated with morphological convergence in burrowing taxa (e.g. Amphisbaenia) are now widely recognised (e.g. Čerňanský et al. 2015; Reeder et al. 2015). Besides, this vertebra is clearly different from amphisbaenian vertebrae which lack a neural spine and present prezygapophyseal processes. Multistate characters were treated as unordered except for character 6 .

The second analysis concerns characters related to the frontal of taxa belonging to the main lizard groups, it includes 11 characters coded in 47 taxa (appendix 4). More taxa are included than in the first analysis, as the skull morphology of lizards has been more extensively studied than their vertebral morphology. The matrix includes 3 fossil taxa (Saniwa ensidens, Merkurosaurus ornatus, Pseudopus laurillardi) and the frontal BFI 1877 studied here. As for the first analysis, most of the characters are drawn from the literature and previous phylogenetic analyses (Estes et al. 1988; Conrad 2008; Smith 2009a; Gauthier et al. 2012; Quadros et al. 2018). Polarity of some characters $(3,5)$ is modified relative to their classic encoding (see justification).

The third analysis includes 11 extant teiid genera and the fossil specimens from the Eocene of Quercy described above. Fifty-nine morphological characters (mainly skull and vertebral characters, see appendix 5) were analysed. Terminal taxa are composite of the available specimens, and fossils are considered of the same taxon. In coding extant genera, the most common state was recorded (less common states are mentioned in text of appendix 5).
When the states are equally common, both are recorded. Most characters are from Presch (1974), Denton and O’Neill (1995), and Nydam et al. (2007), some are modified and some are new characters not previously used in phylogenetic analysis.

The systematics of Teiidae has changed in the past years with the resurrection and proposal of genera, not always with consistent phylogenetic relations resolutions (see Harvey et al. 2012; Goicoechea et al. 2016; Tucker et al. 2016). These studies are based mainly on external, soft anatomy and molecular data (e.g. diagnosis of Salvator and Tupinambis), and therefore are inapplicable to fossil materials. Hence, we follow Nydam et al.'s (2007) osteology-based taxonomy, which does not account for all (now) known diversity but is of use in palaeontology.

Figures and map were elaborated with Inkscape (Inkscape Team, 2019), and QGIS (2,18 Las Palmas) (QGIS Team, 2018), the map based on a XYZ tyle from Google Satellite (http://www.google.cn/maps/vt?lyrs=s@189\&gl=cn\&x= $\{x\} \& y=\{y\} \& z=\{z\}$ : access 1505/2018).

\section{Systematic palaeontology}

Order Squamata Oppel, 1811

Superfamily Lacertoidea Fitzinger, 1826

Family Teiidae Gray, 1827

Tupinambinae Bonaparte, (1831)

Teiidae incertae sedis

Material: Frontal, BFI 1877, MNHN, Ex collection Mathis, La Bouffie, Phosphorites du Quercy (France), late Eocene (Priabonien, MP17), Fig. 2. Incomplete maxilla, PRR 2007, MNHN, Perrière B, Phosphorites du Quercy (France), late Eocene (Priabonian, MP17), Fig. 4. Incomplete maxilla, MAL 615, MNHN, Malpérié, Phosphorites du Quercy (France), late Eocene (Priabonian, MP17). Trunk vertebra, PRR 2006, MNHN, Perrière B, Phosphorites du Quercy (France), late Eocene (Priabonian, MP17), Fig. 5.

\section{Description}

Frontal BFI 1877, (Fig. 2): Incomplete frontal, missing its anterior end; thus, the exact shape of this margin cannot be determined. The frontal is azygous, without any traces of a suture. In general shape, the bone is slightly constricted between the orbits, although the lateral borders are not markedly concave. The frontal reaches its greatest width at the frontoparietal suture where two transversely oriented, small posterolateral processes are present (interorbital width, $5.1 \mathrm{~mm}$; frontoparietal suture, $9.5 \mathrm{~mm}$ ). 


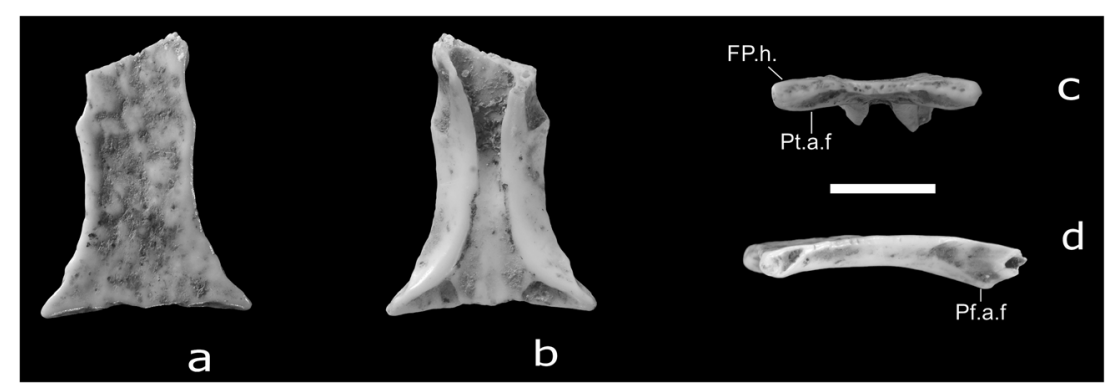

Fig. 2 Frontal, BFI 1877, MNHN, Ex collection Mathis, La Bouffie, Phosphorites du Quercy (France), late Eocene (Priabonien, MP17). a dorsal view; b ventral view; c posterior view; d right lateral view. FP.h., frontoparietal mesokinetic hinge; Pf.a.f., prefrontal articulation facet; Pt.a.f parietal tab articulation facet. Scale bar equals $5 \mathrm{~mm}$

Between these parietal tabs, the frontoparietal suture of extant teiids is more or less strongly interdigitating, following Gauthier (1984) and Estes et al. (1988) (teiid apomorphy according to Gauthier et al. 2012). These interdigitations are hardly visible on the frontal from La Bouffie but, some extant teiid genera (e.g. Tupinambis, Fig. 3) have the same poorly developed frontoparietal interdigitations.

Ontogenetic fusion of the frontals has evolved many times within Squamata and has been considered a synapomorphy of Iguania and of Gekkota, with many independent acquisitions in other taxa (Estes et al. 1988). Following these authors, fusion of frontals in embryonic or early stages of postembryonic ontogeny is a teiid synapomorphy. According to Conrad's (2008) and Gauthier's et al. (Gauthier et al. 2012) more recent phylogenetic hypotheses, frontal fusion is an apomorphy of the Teiioidea (sensu Estes et al. 1988, Teiidae + Gymnophthalmidae).

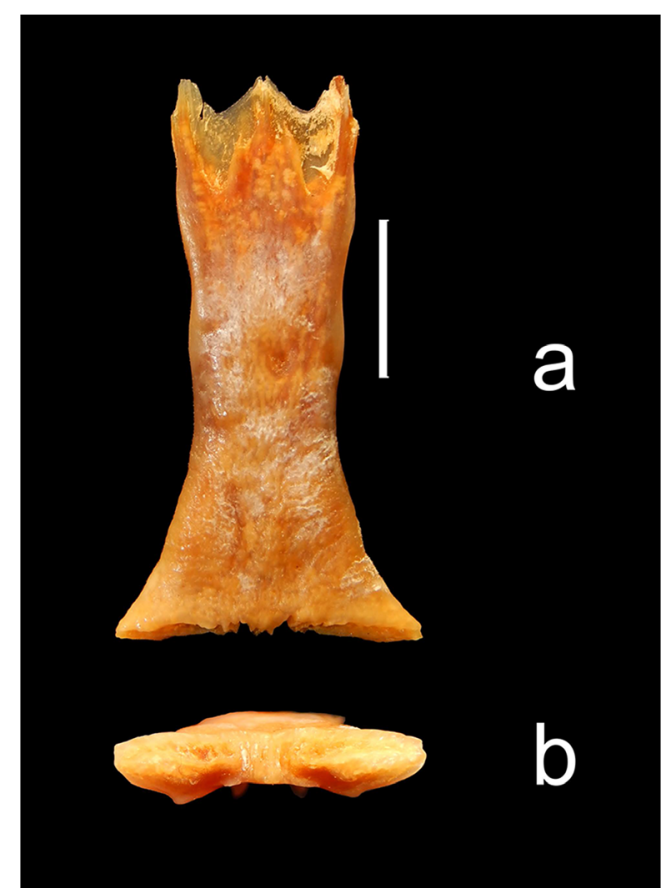

Fig. 3 Frontal, extant Tupinambis salvator (Teiidae). a dorsal view; b posterior view. Scale bar equals $10 \mathrm{~mm}$ 
Estes et al. (1988) consider that developed cristae cranii that restrict contribution of the prefrontal to the orbitonasal fenestra are the common condition in squamates, with the exception of Teiidae and most Iguania. The fossil not only presents shallow cristae cranii but also a large prefrontal articulation facet that allows the inference of an important contribution of the prefrontal to nasolacrimal fenestra. The shallow cristae cranii of the fossil allows differentiation from most gymnophthalmids in which they fuse into an olfactory duct (Presch 1980). The exclusion from this family is more evident because of the absence of posterior frontal tabs that project posteriorly over dorsal surface of parietal (apomorphy of Gymnophthalmidae, Estes et al. 1988).

As stated before the Barbatteiidae, a European Cretaceous clade are considered as sister to the extant teiids (Venczel and Codrea 2016; Codrea et al. 2017). Frontals of the barbatteiids (Barbatteius and Oardasaurus) present extensive osteodermal crust with the evident impressions of cephalic scales (Codrea et al. 2017), unlike BFI 1877. The frontoparietal suture of Oardasaurus glyphis is manifestly serrated and in dorsal view forms an inverted U, unlike the suture in BFI 1877. The known frontal of Barbatteius vremiri is less informative because of the dermal crust development across the frontoparietal suture (Venczel and Codrea 2016).

The concave outline of the frontal also differs from the subparallel borders present in several lizard taxa (see Conrad 2008), in particular the extinct Polyglyphanodontinae (Sulimski 1975). According to Conrad (2008), the Teiidae and Iguania share the same condition regarding constriction of the frontal between the orbit. However, the level of constriction between the orbits, and therefore the hour-glass shape of the frontal is a character state difficult to evaluate because it is expressed as a ratio and the taxonomic level considered in different studies. For example, when Estes et al. (1988: 144) recorded their character 7, that is lateral border of the frontal, they used the term "strongly constricted between the orbits". In that sense, this character occurs in many iguanians but is absent in Teiidae. Estes et al. (1988) and Smith (2009b, character 44) consider that Iguania are diagnosed, among other apomorphies, by a constricted frontal. Gauthier et al. 2012 (characters 48 and 49) try to quantify the degree of interorbital constriction in relation to the frontoparietal suture although they suggest rather arbitrary intervals. Measurements of BFI 1877 and an extant teiid, Tupinambis merianae, give values that correspond to derived states of Gauthier et al. (2012) character 49. However, these authors did not record these characters on their list of teiid synapomorphies.

To sum up this point, the frontal from La Bouffie is moderately constricted between the orbits, a feature that is also fairly common in Teiidae, Gymnophthalmidae, Iguania and some members of Scincoidea or Lacertidae, even those with strong supraorbital flanges.
In addition, some other characters, though not regarded as teiid synapomorphies, may give useful phylogenetic information. This is the case for the lack of cephalic scale impressions on the dorsal surface of the frontal. In recent teiids, head scales are loosely attached to the skull bones (Pianka and Vitt 2003), although according to Codrea et al. (2017: 8), occasionally, some (e.g. Ameiva, Cnemidophorus and Kentropyx) bears attenuated rugosities. To be precise, teiids have cephalic scales and no osteoderms underlying them. In contrast, lacertids have large cephalic scales (scutes) and also cephalic osteoderms. Absence of rugosities is a feature common to all teiid lizards in contrast with the frontal of lacertids that usually bears grooves at the limits of epidermal scutes. The frontal of adult teiids bears low, irregular and poorly defined dermal rugosities (e.g. Pholidoscelis, Fig. 2 in Bochaton et al. 2017: Ameiva according to the nomenclature followed here) and the subcircular swellings that appear on the frontal from $\mathrm{La}$ Bouffie may be interpreted in that sense.

Concerning the articular facets between the frontal and parietal, two kinds of superimposed surfaces are present on each side of the posterior margin of our specimen: 1-A dorsal one, shallow and weakly developed, that corresponds to the lateral articular surface present on the frontoparietal suture of most lizards (i.e. frontoparietal mesokinetic hinge). Versluys (Verluys 1910) defined the term mesokinesis and applied it to any movement in the skull roof anterior to the parietal. Later Frazzetta (1962) restricted its usage to movements at the frontoparietal joint and as recognised by Evans (2008) descriptions of mesokinesis often focus on the frontoparietal hinge line. 2-A ventral one, under-lapping the mesokinetic joint, triangular and well-developed that received the parietal tab (apomorphy of Lacertiformes, sensu Estes et al. 1988). Coexistence of these two articular surfaces seems to be a unique feature of teiid lizards, not seen in lacertids that have only facets for the parietal tabs (Fig. 3). Indeed, among teiids, the dorsal surfaces are slightly more developed (i.e. with more overlap onto the frontal) in the Teiinae, whereas the Tupinambinae present a condition more similar to that of BFI 1877 (i.e. shorter dorsal overlap). BFI 1877 presents a marked ridge between these left and right complex articulations (Fig. 2c). This condition is not observed in extant teiids: in most taxa these pairs are separated by a convex surface and not a marked crest; in some cases, where the frontoparietal suture is deep (i.e. dorsoventrally developed), they are separated by dorsoventrally oriented ridges and grooves (e.g. Ameiva, Tupinambis, the interdigitating part of the frontoparietal suture).

Fragmentary maxilla PRR 2007 (Fig. 4): This specimen is a heavily built fragmentary maxilla (anterior part of a right maxilla, the premaxillary processes and the facial process are broken off) having the first six tooth positions preserved. The lateral surface of the maxilla bears a faint dermal ornamentation consisting of irregular swellings very similar to the 

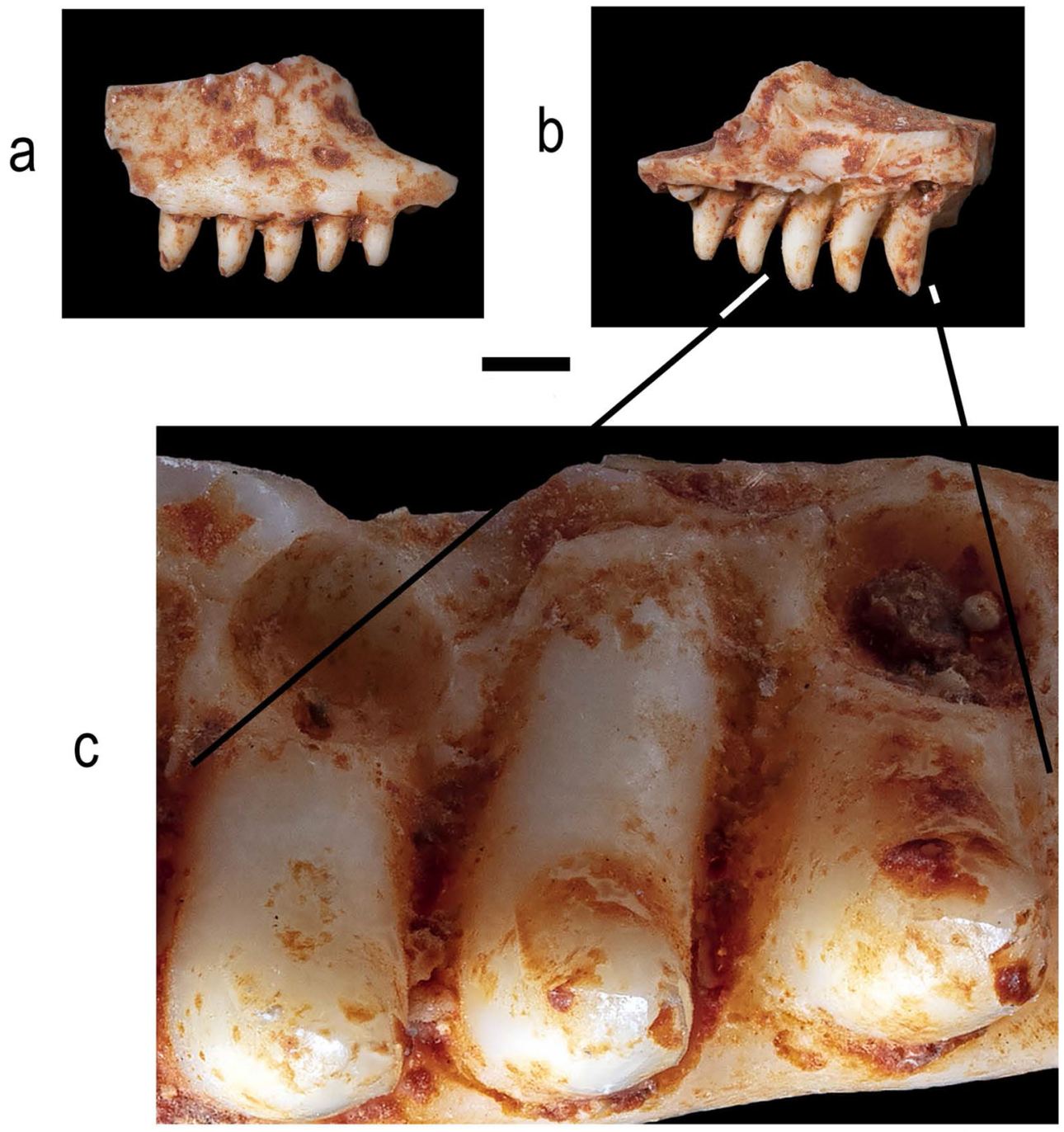

Fig. 4 Incomplete maxilla, PRR 2007, MNHN, Perrière B, Phosphorites du Quercy (France), late Eocene (Priabonian, MP17). a labial view; b lingual view (scale bar equals $5 \mathrm{~mm}$ ); $\mathbf{c}$ dorsal (occlusal) view (scale bar equals $1 \mathrm{~mm}$ )

dermal rugosities seen on the frontal. There is one labial foramen that opens above the level of the third tooth.

In lingual view, the supradental shelf is eroded. The medial face of the facial process is poorly preserved but the basal part of the nasolacrimal ridge is certainly present. A small anterior ridge runs nearly parallel to the anterior margin of the facial process and it may represent the cristae transversalis. This condition is similar to that seen in Tupinambinae (Brizuela 2010, see discussion) but it is a relatively ubiquitous feature in many lizard groups.

The six tooth positions preserved consist of five complete teeth $(b-f)$ and the space for another, more anterior one (a). The three anterior teeth (b-d) are unicuspid, slightly curved with a rounded to obtusely pointed apex. Teeth (e) and (f) are slightly bicuspid (more e than f), and cusps are mesiodistally arranged with the anterior one more diminutive. The dentition is therefore markedly heterodont. No striations are present on any of the teeth. The tooth shafts are robust, their basal half is subcylindrical, then they become conical towards the apex. The tooth bases are firmly cemented to the supradental table (sensu Rage and Augé 2010). Cementum covers vastly the tooth bases and remains even when the teeth are not present, leaving a kind of "alveolus". So, tooth implantation is subpleurodont of the pseudothecodont type (Denton and O'Neill 1995) where cementum fills all the surface of the supradental table. Two large rounded resorption cavities are present lingual to tooth bases (d) and (f), the former smaller than the later whose base is almost entirely resorbed.

Fragmentary maxilla MAL 615: This specimen is a fragmentary left maxilla (posterior part) which preserves only four complete teeth. Their morphology is identical to that of the maxillary teeth from Perrière with extensive cementum deposits around the tooth bases and on the supradental table. The palatal shelf (sensu Oelrich 1956 dorsal part of the supradental table) is wide. There is a shallow depression (jugal facet) along the posterior part of the nasal process. A low ridge 
separates the jugal facet from the flat medial surface of the palatal shelf.

This maxilla may represent the same taxon as the maxilla from Perrière $\mathrm{B}$ on the basis of teiid morphology, comparable size and similarity in tooth morphology.

Actually, tooth morphology is not identical and it slightly differs between the two specimens. In the posterior fragment, the penultimate tooth is short, stocky with a blunt apex. Hence, if both specimens are from the same taxon, the heterodonty includes uni, bicuspid and robust unicuspid (or molariform or amblyodont sensu Estes and Williams 1984; Augé 2005) teeth. This type of heterodonty has been documented in Tupinambis (Presch 1974; Dessem 1985; Kosma 2004; Brizuela and Albino 2010).

\section{Comments}

According to Edmund (1960), tooth replacement of the "iguanid method" is observed in gekkonids, iguanids, scincids, cordylids, xantusiids and lacertids. In iguanids, the replacement pit develops largely in an apical direction. In contrast, replacement pits in teiids affect mainly the base of the teeth and they do not develop much in an apical direction. The lack of marked striations on the teeth favours the exclusion of most Scincoidea that bear apical enamel crest, unlike most lacertids and teiids. Kosma (2004: 166) considers that tooth striations cannot be considered as an autapomorphic character of "Scincomorpha" because they are also present in other groups (i.e. some Anguimorpha). In Teiidae, there are only faint convergent striations in those tupinambines with robust teeth (Tupinambis, Dracaena, and Paradracaena) but there are no marked distinct stria (with the exception of the irregular mesiodistal crest observed in molariform teeth of Tupinambis).

In general, teiid dentition is considered subpleurodont (sensu Presch 1974, and Zaher and Rieppel 1999) where successive tooth positions are delimited by interdental walls or septa (see controversy between Zaher and Rieppel 1999 and Caldwell et al. 2003) which are not always complete. The amount of cementum can help generally differentiate between taxa within the family. Three conditions can be recognised regarding the amount of cementum (see Denton and O'Neill 1995; Nydam et al. 2007; Brizuela 2010); a: taxa with little cementum (Cnemidophorus, Ameiva, Kentropyx, Aspidoscelis); b: taxa with abundant cementum that partially conceals the interdental septa (Crocodilurus, Tupinambis); c: taxa with much cementum that totally conceals the interdental septa (i.e. pseudothecodont) (Dicrodon, Dracaena, Paradracaena, Teius). These conditions are not always clear-cut or evident (the conditions grade into one another). These fossil maxillae seem to conform to the pseudothecodont type.

The assignment of these maxillae is based on several characters which in combination strongly suggest teiid relationships: conspicuous cementum deposit around tooth bases, deep, subcircular replacement pits, "subpleurodont" tooth implantation and marked heterodont dentition (Nydam and Cifelli 2002). These are all teiid synapomorphies according to many authors (e.g. Estes et al. 1988; Pianka and Vitt 2003; Nydam et al. 2007) and shared with Borioteiioidea (Nydam et al. 2007). This type of subpleurodont dentition (sensu Zaher and Rieppel 1999 or pseudothecodont) is observed in some Tupinambinae (Dracaena and the extinct Paradracaena) and some Teiinae (Dicrodon and Teius). In both cases, it is associated with a very particular dentition: large molariform teeth in Tupinambinae, transversely bicuspid teeth in Teiinae. Neither is the case for the fossil material whose dentition would be similar to that of Tupinambis (if both maxillae are from the same taxon). Some specimens of T. merianae present much cementum, close to the pseudothecodont type.

Additionally, the heavily built maxillae and robust dentition are characteristics consistent with teiid affinities.

Trunk vertebra PRR 2006 (Fig. 5). This is a large and robust vertebra, dorsoventrally depressed, and the condyle is broken off. In dorsal view, the neural arch is low, and the vertebra is wide and constricted between the pre- and postzygapophyses. The dorsal surface of the neural arch shows a distinct median crest that rises posteriorly into a neural spine that is incomplete. The neural arch does not completely cover the centrum, of which the anterior edge is visible in dorsal view. The anterior edge of the neural arch shows a well-developed zygosphene that possesses ventrolaterally oriented articular facets. The vertebra is strongly depressed where the zygosphenal articular facets and the prezygapophyses meet so that these two structures seem to form a continuous articular surface. In dorsal view, between the lateral zygosphenal articular surfaces, the roof of the zygosphene is incised. Anteriorly, the zygosphene is thin (but not laminar). The cotyle is oval (dorsoventrally flattened) and it faces anteroventrally, as in most lizards with procoelous vertebrae. However, the ventral rim of the cotyle is not strongly retracted posteriorly, so that the concave surface of the cotyle is slightly exposed in ventral view, in contrast to most Anguimorpha. In anterior view, the outline of the neural canal is triangular and rather constricted. Anterolaterally, the synapophyseal facet is moderately elongated beneath the prezygapophyses and slightly posteriorly inclined. The ventral aspect of the centrum is triangular and bears a wide, rounded sagittal ridge. No subcentral foramina are present.

\section{Comments}

This vertebra shows a characteristic teiid form: depressed, centrum flat and triangular in ventral view, presence of a well-defined zygosphene, presence of a deep depression between the zygosphenal articular facet and the prezygapophysis (Hoffstetter and Gasc 1969; Albino and Brizuela 2014), and taken together, these characters strongly suggest teiid relationships. The trunk 


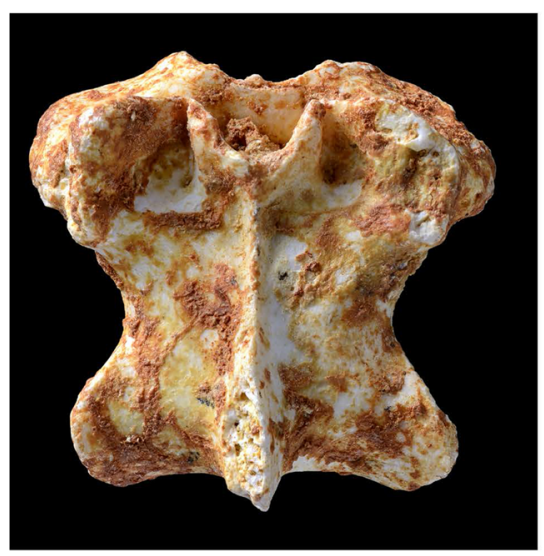

a

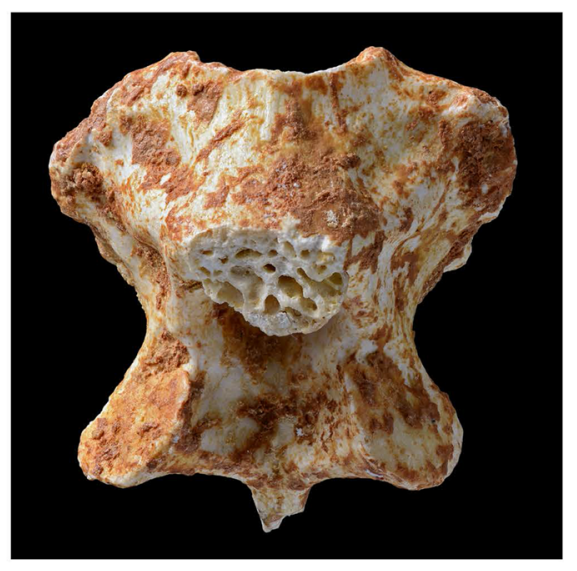

b

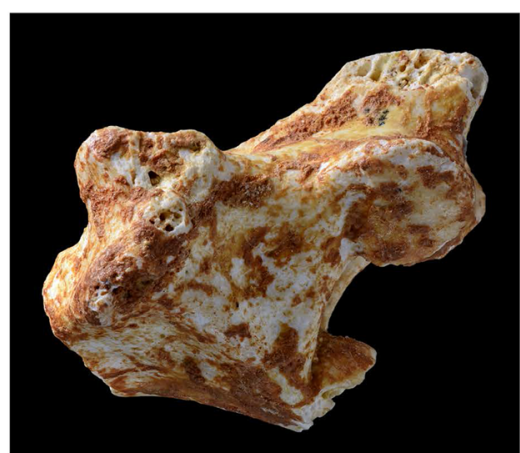

C

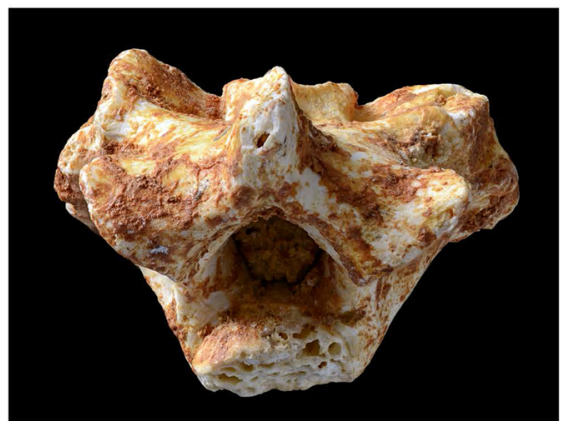

d

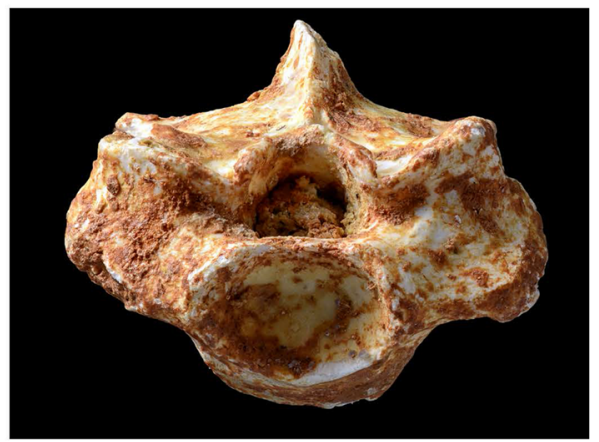

e

Fig. 5 Trunk vertebra, PRR 2006, MNHN, Perrière B, Phosphorites du Quercy (France), late Eocene (Priabonian, MP17). a dorsal view, b ventral view, c lateral view, d posterior view, e anterior view. Scale bar equals $5 \mathrm{~mm}$

vertebrae of the varanid genus Saniwa, present in the European Eocene, share some features with the vertebra from Perrière, in particular a depressed centrum and the presence of a zygosphene. However, the zygosphene on the vertebrae of Saniwa is rudimentary, without any articular surfaces (pseudozygosphene, sensu Hoffstetter and Gasc 1969) and its cotyle shows a definite varanid morphology (articular surface of cotyle directed ventrally) that is absent in the vertebra from Perrière.

Among extant teiids, a small and triangular neural canal and rounded sagittal crest (i.e. without marked borders) are indicative of tupinambine affinities. Variation exists in the depth of the zygosphene among teiids: while in the teiine it is shallow, it is deep in (adult) tupinambine (Albino and Brizuela 2014). The zygosphene in PRR 2006 appears to have an intermediate depth.

\section{Comparisons}

Referral of the specimens described here to the family Teiidae is based on several synapomorphies shared with extant members of the family Teiidae (frontal, maxillae) or a combination of characters that are only present in teiids (vertebra).
The frontal from La Bouffie differs significantly from that of most lizard taxa (in particular Lacertidae and Scincoidea) by its absence of osteodermal covering and scale impressions, its contact with the parietal which involves two structures (ventral facets receiving the parietal tabs and dorsal hinges), and its moderate constriction between the orbits, a feature also present in many iguanids but much more developed in this group, see for example the genus Cadurciguana from the late Eocene of the Phosphorites du Quercy. In addition, the frontal from Cadurciguana bears the mark of the parietal foramen which was located between the frontal and the parietal, a feature absent in frontal BFI 1877. This frontal does not underlap the parietal laterally (no trace of underlap is visible), so it differs from Iguanian (and more generally from Anguimorphan) condition (see Smith 2009a).

The fragmentary maxillae bear amblyodont teeth, like some other lacertid lizards from the Eocene/Oligocene of the Phosphorites du Quercy (Escampcerta; Dracaenosaurus) but teeth of these species do not have a subpleurodont implantation, sensu Zaher and Rieppel 1999. Moreover, Escampcerta, from coeval localities in the Quercy, is considerably smaller than maxillae MAL615 and PRR 2007 and Dracaenosaurus 
(a lacertid from the late Oligocene of Europe, Čerňanský et al. 2016) has mesiodistally elongated amblyodont teeth that differ markedly from the teeth described here. Some extant (e.g. Tiliqua scincoides) or fossil scincids (Pyrenasaurus evansae, Bolet and Augé 2014) bear enlarged teeth but their implantation is different (not subpleurodont) and the posterior part of the maxilla (end of the facial process) is elevated and bears an incision, not present in maxilla MAL 615.

The dorsal vertebra differs strongly from that of lacertid and scincoid lizards by its low neural arch, its nearly smooth ventral surface, with a slightly rounded sagittal ridge, the cotyle and condyle markedly flattened and its welldeveloped zygosphene. The most similar dorsal vertebrae are those of varanid lizards but they lack a zygosphene except for the genus Saniwa, known in the early Eocene of Europe, but its zygosphene is inconspicuous and Saniwa disappears from Europe at the end of the early Eocene.

So all fossils show strong teiid affinities, their size and proportion are rather comparable and they come from the same stratigraphic level (early late Eocene, MP17), and in the case of one maxilla and the vertebra, they come from the same locality. Regarding size, and considering that the 6 tooth spaces of the maxilla PRR 2007 measure $4.9 \mathrm{~mm}$ long and assuming a conservative tooth count of 15 teeth for this maxilla (maxillary tooth count of most extant teiids is between 15 and 20 teeth), gives a rough estimate of the length of the maxilla $(=12.2 \mathrm{~mm})$. This value is consistent with the size of the frontal BFI 1877 (length $=13 \mathrm{~mm}$ ) and of the dorsal vertebra PRR 2006 (dorsal length $=11.5 \mathrm{~mm}$ ).

These fossils come from two different localities, Perrière B and La Bouffie (and even three if we consider the maxilla MAL 615 from Malpérié) and it may be asked if specimens from different localities could be referred to the same species.

The three localities belong to the same geographic and geologic area (Phosphorites du Quercy, France) and sedimentary conditions are similar (see geological setting). Moreover, they are very similar in age (late Eocene, MP17). Actually, if we compare the lizard assemblages from Malpérié, Perrière B and La Bouffie (see Table 1), the set of species from the poor localities (La Bouffie, Perrière B) is a subset of the assemblage of the more diverse locality, Malpérié (nearly all lizard taxa, species or genera present at Perrière or La Bouffie are shared with the assemblage of Malpérié). This pattern points to the similarity between the lizard assemblages from the three localities so that their differences in diversity and abundance mainly reflect differences in quantity and exploitation of the fossiliferous substratum.

Hence, attribution of these fossils to the same species is a plausible option (at least as plausible as the attribution of different fossils from the same locality to the same species) but we consider that the available material is insufficient to allow comparisons with other teiids at the species level.
Phylogenetic study

Among the three analyses performed here (see material and methods), the two first analyses are conducted with subsets of large morphological datasets, limited to vertebral characters (analysis 1) and frontal characters (analysis 2). Why using a subset of large morphological dataset and a different scoring of characters? In phylogenetic analyses including isolated fossils, missing data are a serious nuisance when large morphological datasets are used (e.g. Scotland et al. 2003; Sansom and Wills 2013; Augé and Guével 2018, Villa et al. 2018a, 2018b). Missing data cause taxa to drift down trees from their original position (Sansom 2015) and Guillerme and Cooper 2016 state that the ability to recover the "best" tree decreases as the number of missing data increase.

Now, it is widely recognised that large morphological data sets have so far failed to recover congruent phylogenies of squamate reptiles. In contrast, many authors (e.g. Wiens et al. 2012; Reeder et al. 2015; Pyron 2015) consider that molecular phylogenetic analyses (and combined analyses) have resolved the phylogeny of Squamates that is increasingly supported by new genomic data. According to these analyses, gekkonids (with Dibamidae) are regarded as the most basal lizard group and character states in our analyses are scored in accord with this phylogenetic topology. Hence, our choice of a subset of large data set. How to judge merits or failure of this partition of data? The answer is straightforward: phylogenetic hypotheses which are derived from morphological data can be tested with combined or molecular studies. The likelihood that congruent results are independent and reflect the true phylogeny is high. In other words, recovering a morphological tree that approximates the combined or molecular trees would be an important stepping-stone on the way to inferring phylogenetic relationships of extinct taxa.

\section{Results}

Three equally most parsimonious trees are recovered from the first matrix (vertebral characters) (length (L) 48, consistency index (Ci) 0.58, retention index (Ri) 0.84). These trees were used for the strict consensus tree (Fig. 6, L 49, Ci 0.57, Ri 0.83), with two nodes collapsed. Bremer Support values for trees one step longer than the most parsimonious trees: clade vertebra Quercy + Ameiva $=100$; clade Iguania + Anguimorpha $($ Toxicofera $)=33$. In each of the four trees, the fossil vertebra from the Eocene of Quercy forms a monophyletic group with the teiid genus Ameiva. Interestingly, the results of this analysis are largely congruent with those of recent molecular and combined analyses of lizard phylogeny (e.g. basal position of Gekkota, Iguania included in Anguimorpha, see Pyron et al. 2013; Reeder et al. 2015) which reinforces the confidence in the results of this analysis. However, in this case, the analysis fails to recover lacertids and teiids as a monophyletic group. An 
Table 1 Nestedness: Distribution of lizard taxa among the MP17 (late Eocene) localities from the Phosphorites du Quercy. Taxa in species poor localities (La Bouffie, Perrière, Aubrelong) form subsets of those of the most diverse locality (Malpérié). Only three taxa (out of 20) present at La Bouffie and Perrière are absent from Malpérié. Data in Augé 2005 and Bolet and Augé 2014

\begin{tabular}{lll}
\hline MP17 & Malpérié & La Bouffie \\
\hline Iguania & & \\
& Iguanidae & \\
& Geiseltaliellus lamandini & \\
& Geiseltaliellus pradiguensis & \\
& Cadurciguana hoffstetteri & Cadurciguana hoffstetteri \\
& Pseudolacerta mucronata &
\end{tabular}

Gekkota

$$
\text { Cadurcogekko piveteaui Cadurcogekko piveteaui Cadurcogekko piveteaui }
$$

Lacertoidea

Lacertidae

Teiidae sp.

Lacertoidea

incertae sedis

Scincoidea

Scincidae

?Cordyliformes

Anguimorpha

Anguidae

Glyptosaurinae

Anguinae

Platynota

Helodermatidae

$$
\begin{aligned}
& \text { Plesiolacerta lydekkeri } \\
& \text { Quercycerta maxima } \\
& \text { Gracilicerta sindexi }
\end{aligned}
$$

Teiidae sp

$$
\text { Brevisaurus smithi }
$$

\section{Orthoscincus malperiensis}

Eocordyla mathisi

Plesiolacerta lydekkeri
Gracilicerta sindexi
Escampcerta amblyodonta
Teiidae $\mathrm{sp}$

Teiidae sp

Plesiolacerta lydekkeri Quercycerta maxima Gracilicerta sindexi

Teiidae sp
Perrière $\mathrm{B}$

Geiseltaliellus lamandini 
Table 1 (continued)

\begin{tabular}{|c|c|c|c|c|}
\hline MP17 & & Malpérié & La Bouffie & Perrière $B$ \\
\hline & Lacertidae & & & \\
\hline & Plesiolacerta lydekkeri & $X$ & $\mathrm{X}$ & $\mathrm{X}$ \\
\hline & Quercycerta maxima & $\mathrm{X}$ & & $\mathrm{X}$ \\
\hline & Gracilicerta sindexi & $\mathrm{X}$ & $\mathrm{X}$ & $\mathrm{X}$ \\
\hline & Escampcerta amblyodonta & & $\mathrm{X}$ & \\
\hline & Teiidae & & & \\
\hline & Teiidae indet & $\mathrm{X}$ & $\mathrm{X}$ & $\mathrm{X}$ \\
\hline \multicolumn{5}{|c|}{ Scincoidea } \\
\hline & Scincoidea indet A & & & \\
\hline & Scincoidea indet B & & & \\
\hline & Scincidae & & & \\
\hline & Orthoscincus malperiensis & $X$ & & \\
\hline & ?Cordylidae & & & \\
\hline & Eocordyla mathisi & $\mathrm{X}$ & & \\
\hline \multicolumn{5}{|c|}{ Anguimorpha } \\
\hline & Anguidae & & & \\
\hline & Placosaurus sp & $X$ & $X$ & $\mathrm{X}$ \\
\hline & cf Anguis & $\mathrm{X}$ & $X$ & $\mathrm{X}$ \\
\hline & Ophisaurus s.l. & $\mathrm{X}$ & $\mathrm{X}$ & $\mathrm{X}$ \\
\hline & Helvetisaurus & & & $\mathrm{X}$ \\
\hline & Necrosaurus & $X$ & $X$ & $\mathrm{X}$ \\
\hline & Helodermatidae & & & \\
\hline & Eurheloderma gallicum & $\mathrm{X}$ & $\mathrm{X}$ & \\
\hline \multicolumn{5}{|c|}{ Amphisbaenia } \\
\hline & Blanidae & & & \\
\hline & Blanidae indet & $X$ & $\mathrm{X}$ & $\mathrm{X}$ \\
\hline
\end{tabular}

analysis of the same dataset conducted with the New Technology Search program in TNT gives nearly the same results, and the strict consensus tree (Fig. 7, L 48, $\mathrm{Ci} 0.58, \mathrm{Ri}$ 0.84 ) is perfectly congruent with molecular or combined
Fig. 6 Strict consensus tree of three most parcimonious trees from the analysis of members of the main lizard families (except Amphisbaenia) and the vertebra from the Quercy (PRR 2006), conducted with TNT traditional search. Ameiva (an extant teiid genus) and Quercy vertebra are sister taxa

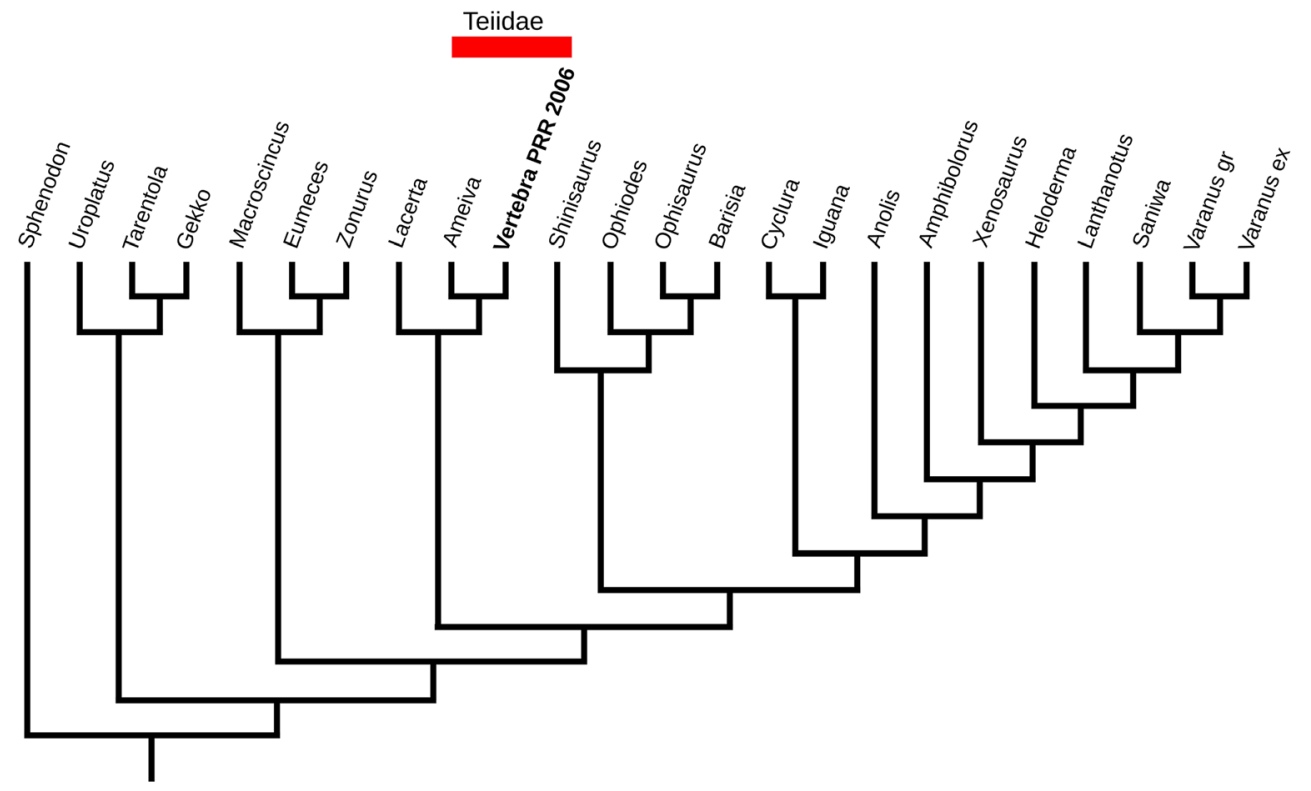


phylogenetic analyses of lizards (except for arrangement within Anguimorpha). In particular, it recovers the monophyletic group Lacertoidea (teiids and lacertids).

The second analysis (frontal characters) gives 38 equally most parsimonious trees (L 27, Ci 0.51, Ri 0.89). The strict consensus tree (Fig. 8, L32, Ci 0.43 , Ri 0.85 with 8 nodes collapsed) shows that the frontal from the Eocene of Quercy forms a monophyletic group with the teiid species Ameiva ameiva and Tupinambis merianae. Another analysis, with the same taxa and characters (except character 4 that has been excluded) gives 38 equally most parsimonious trees (L 23, Ci 0.52 , Ri 0.90 ) resulting in a strict consensus tree after 8 nodes have been collapsed (Fig. 9, L 28, Ci 0.42, Ri 0.86). Bremer Support values for trees one step longer than the most parsimonious trees: clade frontal Quercy, Tupinambis merianae, Ameiva ameiva $=100$; clade Iguania + Anguimorpha $($ Toxicofera $)=33$. The reason for excluding character 4 (subolfactory processes contact) from the analysis is that this character may be associated with false phylogenetic signal as its derived state is only present in Gekkota and varanids. These taxa are widely recognised as, respectively one of the most basal lizard group (Gekkota) and one of the most derived (varanids). Once again, the results of these two analyses are largely congruent whith those of recent molecular and combined analyses of lizard phylogeny, in particular a monophyletic clade including Anguimorpha and Iguania is recovered (cf Toxicofera sensu Vidal and Hedges 2005) with a new morphological apomorphy, character 9 (frontal underlaps parietal laterally). These two analyses also support the placement of the frontal BFI 1877 within Teiidae.
Four equally most parsimonious trees are recovered from the third analysis (extant teiids + fossil specimens) with TNT (length (L) 85 steps, consistency index (Ci) 0.83 , retention index (Ri) 0.83). The resulting trees were used for the strict consensus tree (Fig. 10, L 92; Ci 0.77; Ri 0.75). In this case, the fairly high retention and consistency indices indicate that there is relatively little homoplasy in our morphological dataset (Klingenberg and Gidaszewski 2010).

The fossil specimens are recovered as sister to the extant genus Dracaena, highly nested in a group including the extant genera Callopistes, Crocodilurus, Dracaena and Tupinambis, confirming the monophyly of the subfamily Tupinambinae (Estes et al. 1988). These results suggest that the Eocene fossils from the Quercy belong to this subfamily. The Tupinambinae are nested in a large polytomy with the rest of the teiids, the Teiinae failing to form a monophyletic group.

Hence, it is clear from these analyses and descriptions that the lizard fossils studied here belong to teiid lizards and more specifically the third analysis suggests that they belong to the subfamily Tupinambinae.

\section{Origin of European teiids}

\section{Atlantic crossing}

If teiid lizards were present in Europe during the late Eocene (MP17), one critical question arises: where did they come from? This question (geographical origin of European teiids) leads to different proposals: The most straightforward

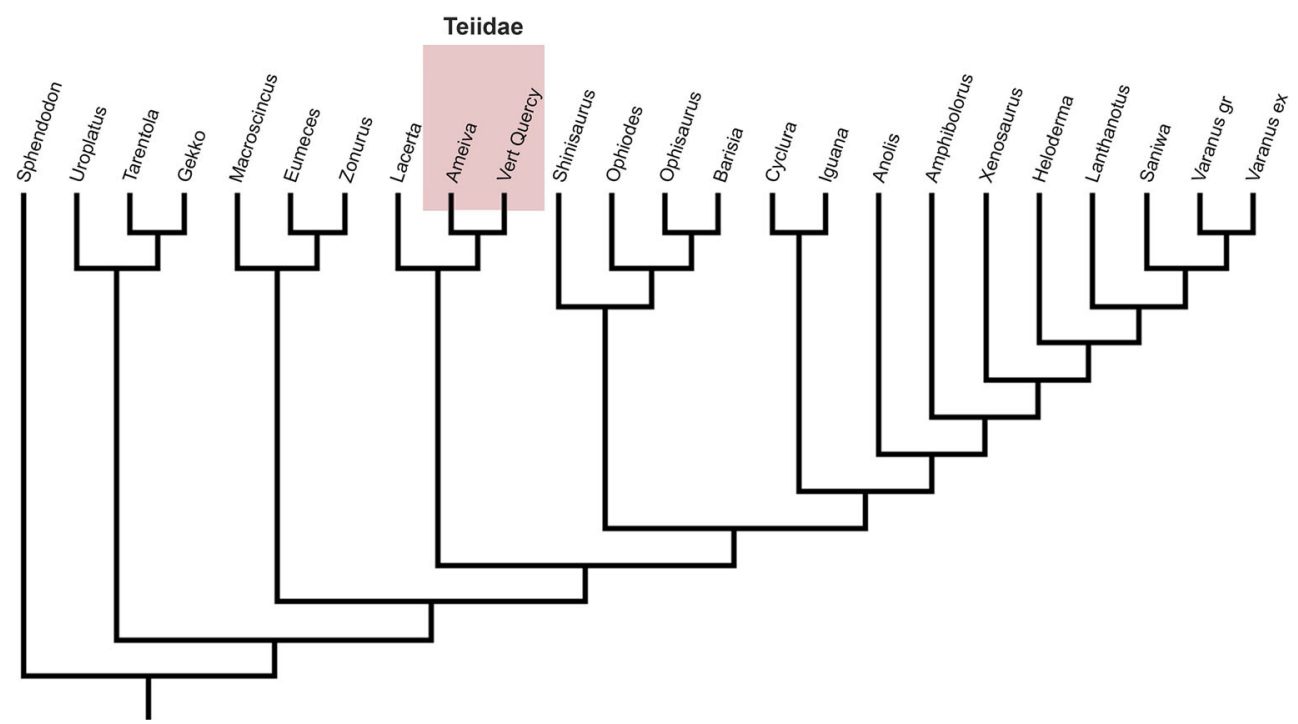

Fig. 7 Strict consensus tree of three most parcimonious trees from the analysis of members of the main lizard families (except Amphisbaenia) and the vertebra from the Quercy (PRR 2006), conducted with TNT new search program. Ameiva and Quercy vertebra are sister taxa, monophyly of Lacerta and teiids is also recovered. Note the general conformity of the topology of this tree with results obtained from molecular analyses of extant lizards, except for the placement of Iguania within "Anguimorpha" 


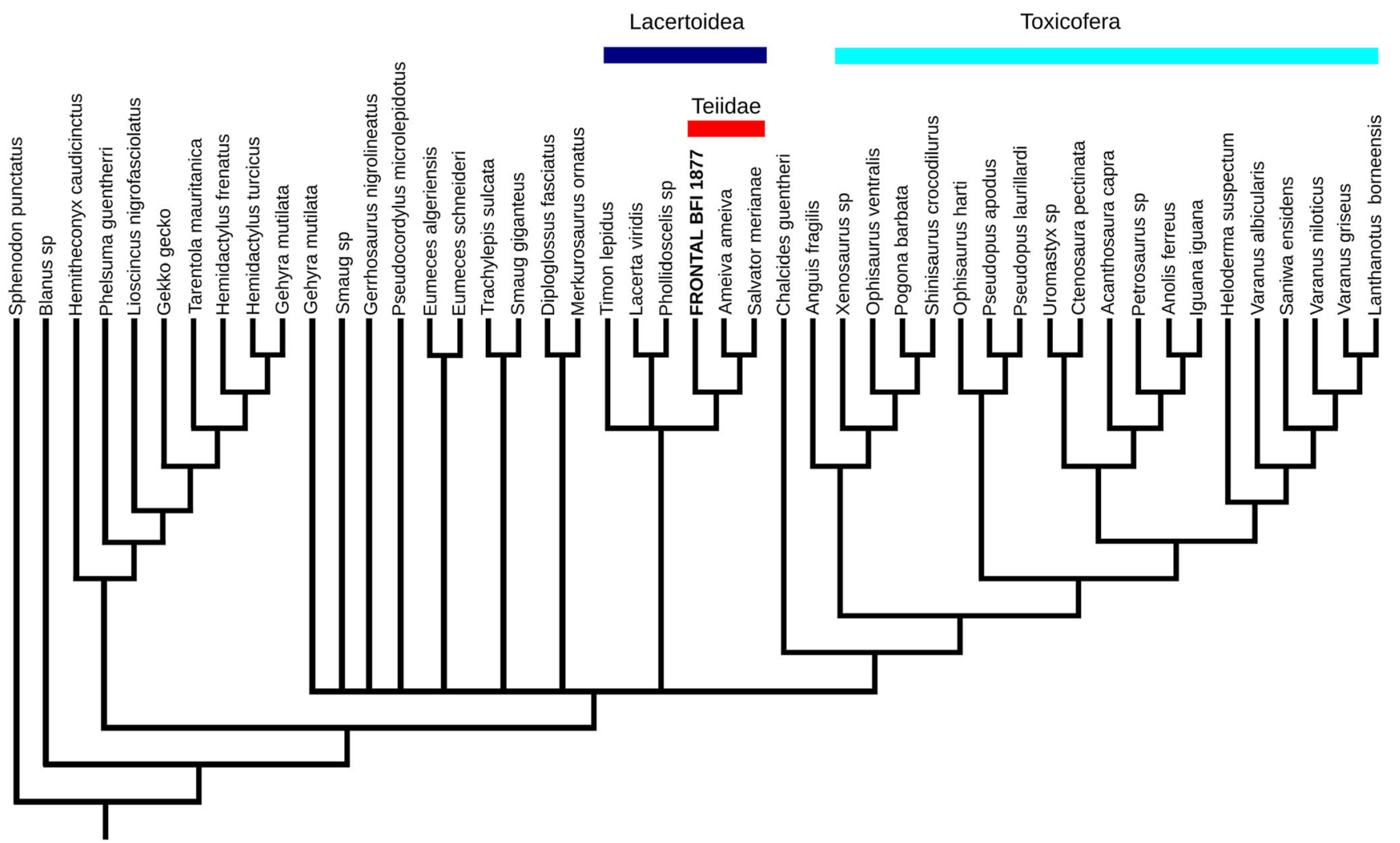

Fig. 8 Strict consensus tree (L 32, Ci 0.42, Ri 0.85) resulting from the analysis of 11 morphological characters of the frontal taken from 44 extant lizard taxa representing the main lizard families, three fossil lizards (Saniwa, Merkurosaurus, Pseudopus laurillardi) and the frontal BFI 1877. Ameiva ameiva, Salvator merianae (extant Teiidae) and

hypothesis implies a European origin: Several lizard remains from the Late Cretaceous have already been referred to Teiidae or taxa regarded as closely related to Teiidae in Europe (Chamopsiidae, Borioteiioidea, see Gheerbrant et al. 1997; Rage 1999; Folie and Codrea 2005; Makádi 2006, 2013a, 2013b, Barbatteiidae see Codrea et al. 2017). None of these Late Cretaceous taxa persisted into the European Paleogene.

Extant teiids are only known in the New World (they are widely distributed in South America, with some genera reaching Central and North America and the West Indies, Harvey et al. 2012). Historically, it has been stated that teiids (sensu lato, e.g. Nydam et al. 2007) had a wider distribution, chiefly in the Late Cretaceous, when an extinct basal group, polyglyphanodontines (Borioteiioidea sensu Nydam et al. 2007) was diverse in Asia (Mongolia), Europe and North America. The fossil record indicates that all these Northern Hemisphere teiids became extinct by the end of the Cretaceous, presumably as a result of the $\mathrm{K} / \mathrm{Pg}$ extinction event (Longrich et al. 2012). However, due to the rarity of Paleocene lizard fossils, this disappearance may be the result of sampling artefacts. Longrich et al. (2012) rejected this possibility for the fossil record of North America and, in the same vein, the studies
Quercy frontal form a monophyletic group. Note also the general conformity of the tree topology with those obtained from molecular and combined analyses, in particular a monophyletic clade including Iguania and "Anguimorpha" is recovered (Toxicofera)

of Paleocene fossil localities in Europe (Folie 2006; Smith et al. 2014) confirmed the absence of Borioteiioidea and certainly of Barbatteiidae after the $\mathrm{K} / \mathrm{Pg}$ boundary.

Recent phylogenetical investigations suggested that the purported early teiids were actually distantly related to the teiid group and even to Lacertoidea. For instance, Gauthier et al. (2012) state that polyglyphanodontians lack several apomorphies associated with crown Sclero- glossa (i.e. major squamate clades except Iguania) and far from being stem teiids (e.g. Estes 1983), they are stem Scleroglossa, but the authors did not consider chamopsiid lizards in their analysis. What is clear is that the systematic position of the borioteiioid lizards is in a state of flux and could continue to shift with new analyses (Nydam 2013).

An important implication of these results is that the family Teiidae (sensu stricto $=$ crown teiids) has no known Paleocene or early Eocene record in Europe and perhaps in the Mesozoic rendering endemic evolution of teiids in Europe an improbable alternative. Hence, the disjunct distribution of teiid lizards during the Eocene (South America and Europe) requires another explanation, particularly given the context of "splendid isolation" (Simpson 1980) that characterised South America during most of the Cenozoic. The radiation of teiids and their arrival in 


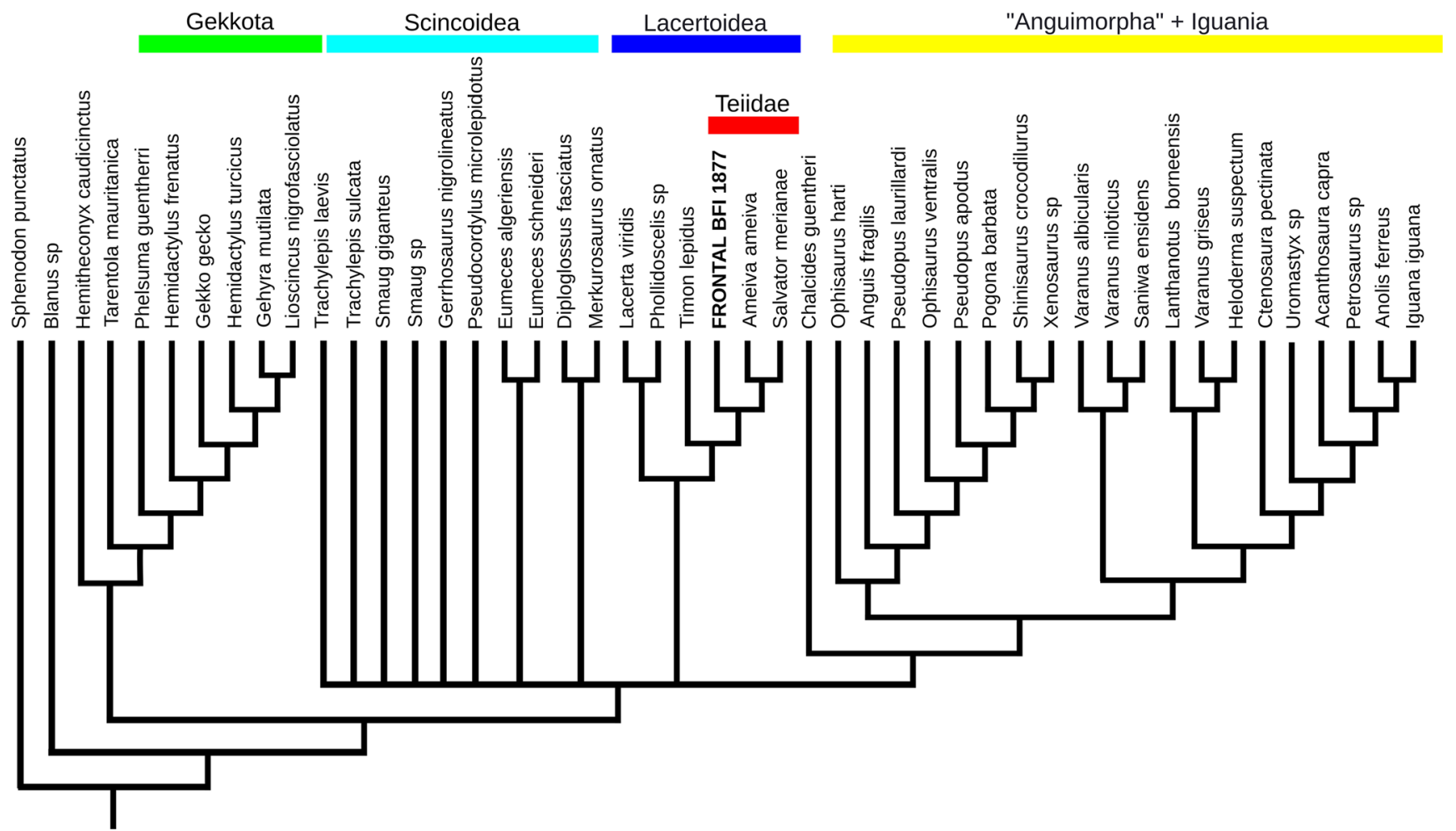

Fig. 9 Strict consensus tree (L 28, Ci 0.43, Ri 0.86) resulting from the analysis of the same matrix than those in Fig. 8, except character 4 has been deactivated. The same general topology is preserved, in particular extant teiids and frontal BFI 1877 form a monophyletic assemblage. Note also that there are a smaller amount of nodes in this consensus tree than

Europe post-date the major episodes of continental movement that marked the break-up of Gondwana by a considerable period. In the Eocene, the Atlantic margins of South America and Africa were already widely separated and South America has been continuously surrounded by oceans from the early the strict consensus tree in Fig. 8 and that the $\mathrm{Ri}$ and $\mathrm{Ci}$ are slightly more significant than in analysis Fig. 8. These results may confirm the potential nuisance of convergent characters to morphological phylogenetic analyses

Eocene to the Pliocene (splendid isolation), so no obvious vicariant event can explain the distribution of Eocene Teiidae.

Altogether, the fossil record favours the hypothesis that Eocene European teiids came from elsewhere and their recent distribution strongly supports migration from the New World.

Fig. 10 Strict consensus tree of four most parsimonious trees from the analysis of extant teiids + fossil specimens from the Phosphorites du Quercy

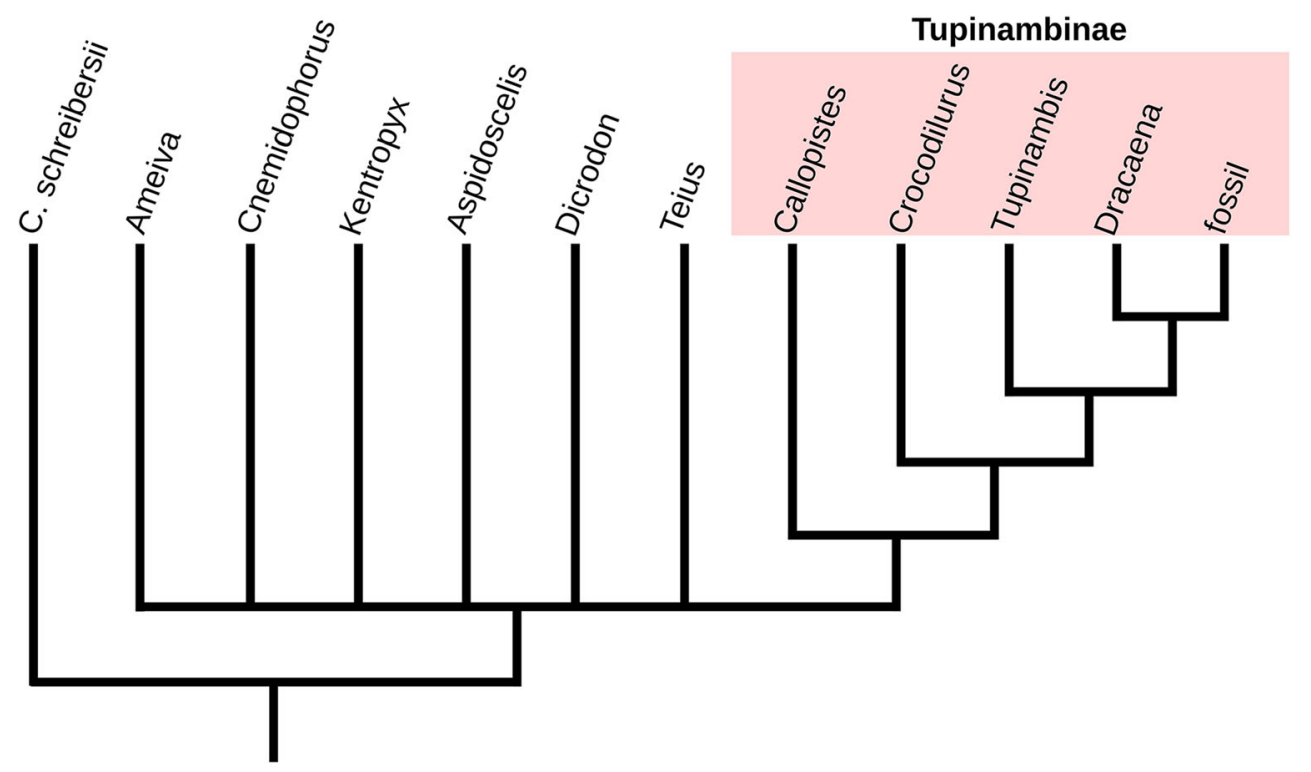


South American origin of Teiidae is well supported both by palaeontological and molecular data; thus, the possibility of transatlantic dispersal must be favoured. Two main hypotheses may be proposed:

1. The dispersal of Teiidae to Europe may have occurred via a northern route (North America). Northward dispersal of South American elements (Teiidae in particular, Giugliano et al. 2007) may have been facilitated by a structure formed by the Greater Antilles which connected to South America near the Eocene/Oligocene transition (Iturralde-Vinent and MacPhee 1999).

2. Dispersal via a Southern route, where Africa may have played the role of a stopover for migrating teiids.

Either hypothesis has its shortcomings, the first being the absence of fossil teiids in the Paleogene of Africa and North America.

Faunal exchanges between North America and Europe are well documented in the early Eocene (migrations tied to the PETM, Paleocene/Eocene Thermal Maximum) and they encompass a wide range of taxa, the best-known being the mammals and to a lesser degree the lizards (Augé 2003; Smith et al. 2006; Smith 2009a). However, no teiid fossil is known in the numerous and well-studied fossiliferous localities of North America (Smith 2009b; Smith 2011; Smith and Gauthier 2013) or Europe (Rage 2013; Augé 2005) during this period. Then, faunal exchange between North America and Europe severed after the early Eocene, and since that time, their squamate fauna follow a separate way.

Here, we favoured the scenario that implies the southern route because classic cases of transatlantic dispersal between Africa and South America are well documented for caviomorph rodents and primates (New World monkeys, platyrrhines) during the late Eocene-Oligocene period (Poux et al. 2006; Antoine et al. 2012). It is also well worth noting that transatlantic dispersal of amphisbaenians during the Paleogene has already been suggested (Vidal et al. 2008), as well as westward dispersal of the scincid Mabuya (Carranza and Arnold 2003) and of several gekkonid taxa (Carranza and Arnold 2006; Gamble et al. 2011).

Moreover, transtethys faunal exchanges between Africa and Europe are well documented during the Eocene (e.g. Gheerbrant and Rage 2006; Angst et al. 2013). For instance, among lizards, the presence of cordylid remains in the late Eocene of Spain (locality of Sossis, Bolet and Evans 2013) and possibly of France (Phosphorites du Quercy, Augé 2005) is the result of dispersal from Africa.

Physical context

Direct land connection between Africa and South America was severed after the Late Cretaceous and by the middle
Eocene the shortest distance between them exceeded 1000 km (Sclater et al. 1977; Scotese 2004; Eagles 2007). Hence, if land vertebrates migrated from one continent to the other after this period, some kind of transatlantic dispersal must have occurred (Hoffstetter 1972; De Oliveira et al. 2009).

The currents of the South Atlantic gyre (a counterclockwise pattern of water circulation, Haq 1981; Parrish 1993) began after the formation of deep water connection between South and Central Atlantic basins (at least since $50 \mathrm{Ma}$, early Eocene, De Oliveira et al. 2009).

It seems reasonable to assume that the direction of major transatlantic dispersal events between Africa and South America is unidirectional and westwards and the idea that west-to-east dispersal is possible is regarded with scepticism. The reason is that the curvature and rotation of the earth give rise to the Hadley circulation (winds) and ocean currents that run east to west in the tropical latitudes (the so called Atlantic South Equatorial Current, SEC, Peterson and Stramma 1991; Bourles et al. 1999) (Fig. 11). The most likely scenario explaining migration of Caviomorpha rodents and Platyrrhines primates would have been an equatorial route that utilised the SEC which is the northern portion of the South Atlantic gyre. When the SEC meets the South American continent, a portion of the SEC (the Brazil Current) flows South to the Equator along the Brazilian coast to the offshore of the Rio de la Plata. In the southern part of the South Atlantic gyre, southeastward-flowing winds drive eastward-flowing currents (South Atlantic Current, SAC, Mc Cartney 1977) (Fig. 11). According to Vianna and Menezes (2011), the latitudes between $35^{\circ} \mathrm{S}$ and $40^{\circ} \mathrm{S}$ are dominated by eastward flows and east of the Rio Grande Rise this eastern current is intensified. The SAC passes south of Rio Grande Rise and the Walvis Ridge $\left(20-30^{\circ} \mathrm{S}\right)$ that $50-60$ Ma ago constituted a set of islands and shallow waters (De Oliveira et al. 2009) that would have favoured transatlantic migration.

The South Atlantic Current is a natural vector for an eastward transatlantic journey. Two main objections may be raised against this hypothesis: 1 - the SAC meets the Antarctic Circumpolar Current (AAC), so it may be too cold to convey mostly tropical animals. 2-This current is weaker than its counterpart in the North Atlantic (Gulf Stream) and too slow to transport South American animals to Africa.

However, the SAC is distinct from the Antarctic Circumpolar Current and is separated from it by the Subtropical Front (Stramma and Peterson 1990). This front stretches across most of the South Atlantic and Deacon (1933) observed a sudden change in surface temperature of at least $4{ }^{\circ} \mathrm{C}$. According to Deacon (1937), the surface waters just north of the front have minimum temperatures ranging from $11.5{ }^{\circ} \mathrm{C}$ in winter to $14.5^{\circ} \mathrm{C}$ in summer and are often warmer by $5{ }^{\circ} \mathrm{C}$ or more. Then, the Subtropical Front operates as a northern boundary to the cold waters of the Antarctic Circumpolar Current. To be fair, 


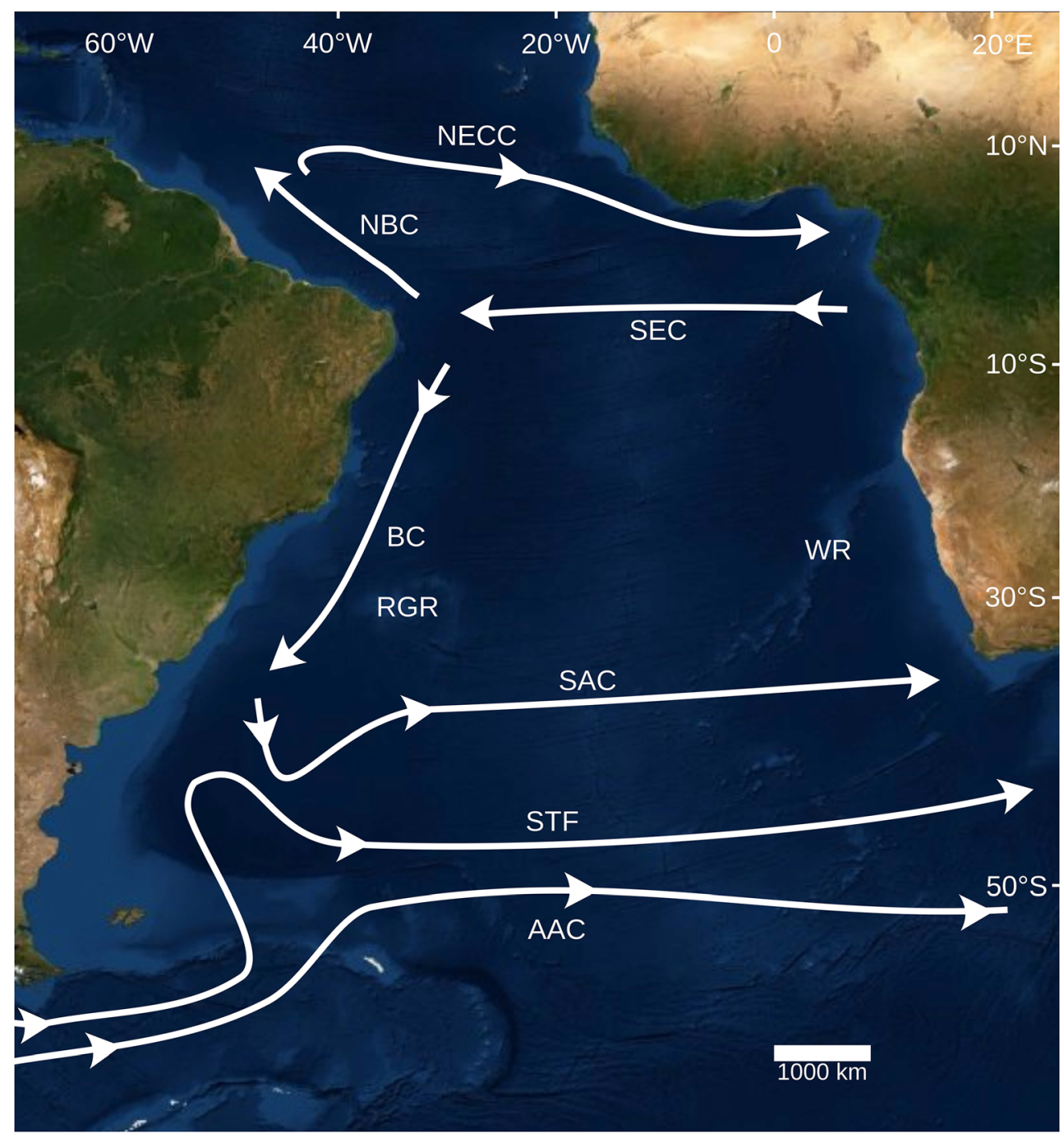

Fig. 11 Map Atlantic: schematic representation of the upper-level currents in the South Atlantic Ocean. Surface currents of the South Atlantic Ocean modified from Peterson and Stramma 1991 and Lawver et al., not published. AAC, Antarctic Circumpolar current; BC, Brazilian current; NBC, North Brazilian current; NECC, North Equatorial Counter current; SAC, South Atlantic current; SEC, Atlantic South Equatorial current; RGR, Rio Grande ridge; STF, subtropical front; WR, Walvis ridge .

the surface velocities of the SAC are not large (they are on the order of $20 \mathrm{~cm} / \mathrm{s}$, Roden 1986) when compared with those of the South Equatorial Current where westward velocities often reach $50 \mathrm{~cm} / \mathrm{s}$ (Peterson and Stramma 1991).

On the other hand, it has often been suggested that large seafloor plateaus such as the Rio Grande Rise or the Walvis Ridge may have been an intermediate stop for mammals migrating from Africa to South America during the Paleogene (De Oliveira et al. 2009). However, the Walvis Ridge and Rio Grande Rise are situated in the southern part of the South Atlantic gyre (Fig. 11), so it is highly improbable that these structures have ever been an intermediate stop for mammals migrating from Africa to South America. On the contrary, at the latitude of these ridges, any South American rafts would
Obviously, there is no current running from Africa to South America near those ridges and if they have been an intermediate stop for vertebrate migrants, the Brazil Current and the SEC would have swept any raft first southward and then eastward towards Africa. Lawver, L.A., Dalziel, L.M., Grahagan, L.M., Intercontinental Migrations Routes for South American Land Mammals: Paleogeographic Constraints

have been swept southward by the Brazil Current and then eastward towards Africa, and according to Vianna and Menezes (2011) east of the Rio Grande Rise the eastern currents are intensified.

Moreover, equatorial surface currents are not limited to the south of the South Equatorial Current (SEC) but they involve a complex system: the SEC bifurcates on the coast of Brazil. Its Northern branch, the North Brazil Current (NBC), turns back and maintains a consistent eastward current that flows into the North Equatorial Counter Current (NECC, Fratantoni et al. 2000). The NECC runs eastward and transports water against the mean westward wind stress in the tropics. The mean eastward velocity for the NECC is $30 \mathrm{~cm} / \mathrm{s}$ and maximum velocities of up to $50 \mathrm{~cm} / \mathrm{s}$ have been measured in the 
winter (Richardson and McKee 1984; Arnault 1987; Fratantoni 2001).

The Atlantic NECC is characterised by its extreme seasonality and variability (Carton and Katz 1990; Fratantoni et al. 2000). Interestingly, this large-scale variability has been in part linked to the El Niño/Southern Oscillation phenomenon (ENSO) in the Pacific. A response to El Niño events occurs in the tropical Atlantic, and coincide with intensification of the NECC (Hisard 1980).

To sum up, the upper-level circulation in the South Atlantic Ocean does not prevent eastward migrations between South America and Africa and isolated events like ENSO could even favour this direction. ENSO phenomena have been proposed for the early-middle Eocene based on sequence analysis of pollen profiles at Messel (Lenz et al. 2016). There are at least two possible routes, both have their pros and cons and neither can be dismissed at present.

In the same vein, two papers (Sanmartin et al. 2007; Linder et al. 2013) have investigated the existence of dispersal asymmetry in the Southern Hemisphere and more specifically whether inferred asymmetries are consistent with the direction of the West Wind Drift (i.e. westward flowing winds and the associated currents). Contrary to expectations, these studies did not detect any significant directional asymmetry in longdistance dispersal events.

\section{Candidates for migration}

Phylogenetic reconstructions favour dispersal from Africa to South America for rodents and primates (see references above), bats (Lim 2009; Springer et al. 2011), birds with limited flight capability as the hoatzin (Mayr et al. 2011) and lizards (amphisbaenians, Vidal et al. 2008; geckos, Carranza et al. 2000; scincids, Carranza and Arnold 2003).

The presence of land vertebrates with purported South American affinities in Europe has already been suggested (Mourer-Chauviré 1999; Rage 1999). These early records have not been confirmed, like the purported European xenarthran Eurotamandua (Storch 1981; Storch and Habersetzer 1991). Recent studies of this animal from Messel suggest it is related to Pholidota, not Xenarthra (Delsuc et al. 2001; Rose 2012).

New studies suggest dispersal from South America to Africa for invertebrates (e.g. land snails, Woodruff and Mulvey 1997), and vertebrates (here restricted to terrestrial taxa), lizards (Amphisbaenidae, Ezcurra and Agnolin 2012; geckos, Gamble et al. 2011) and birds (terrestrial "Terror" birds, Mourer-Chauviré et al. 2011; Angst et al. 2013). Among invertebrates, dispersal by birds is a prevalent mechanism for land snails (Rees 1965; Gittenberger 2012).

Rafting on floating vegetation has been repeatedly suggested for vertebrates (adults or eggs) migrating from Africa to South America (Hoffstetter 1972; Houle 1999), Africa to
Madagascar or around the Caribbean (Losos 2009), sweepstakes dispersal according to Simpson 1940). Some early proposals include Matthew's (1915) calculations about the frequency of observed vegetation or natural rafts and he concluded that rafting is a reasonable explanation for small mammal dispersal.

Lavers (2000) gave a confirmed range of rafting for lizards of $1500 \mathrm{~km}$, and Censky et al. (1998) made observations of over-water dispersal of green iguanas between islands in the Caribbean. Anolis lizards have recolonised islands denuded by hurricanes in the Bahamas up to $300 \mathrm{~km}$ away (Calsbeek and Smith 2003). In the Afrotropical region, phylogenetic studies of gekkonids (Kluge and Nussbaum 1995) and chameleons (Raxworthy et al. 2002) have implicated over-water dispersal from Madagascar to Africa. A major aspect of these reports is that all the confirmed successful sweepstakes events have involved reptiles and more precisely lizards. These ectothermic vertebrates do not face the high energy demands of mammals. In addition, heterothermy is a daily reality in reptiles (Malan 1996; Mc Nab 2002) and many species also readily enter dormancy during climatic fluctuations, seasonal drought or shortage of food resource (Zug 1993; Bradshaw 2003). Long-distance drift is expected to be favoured by the low energy demand of lizards, their resistance to starvation and the capability of some lizards (e.g. Anolis) to store sperm, among other characters. An additional ability of the Teiidae that would have facilitated long-distance rafting is that many of its members are excellent swimmers (e.g. Kentropyx striata) and some are even considered semi-aquatic (fresh water, e.g. Crocodilurus, Dracaena), while others (Tupinambis merianae) are known to withstand long periods of time submerged under water (Ávila-Pires 2000). However, this argument must be put into perspective as teiids are fresh water swimmers which does not guarantee their survival in oceanic water.

At this point, it may be worth noting that several authors have suggested that the over-water dispersal of lemurs, tenrecs and rodents to Madagascar was facilitated by their ability to lower their energy demands by going into a state of torpor or hibernation (Martin 1972; Yoder 1996; Kappeler 2000; Yoder et al. 2003). In the same vein, Hoffstetter (1980) suggested that the colonization of South America by platyrrhines monkeys from Africa may be tied to their 'plesiomorphic heterothermy', as he saw torpor as a character that was likely to have been present in all ancient primates.

Cossins and Barnes (1996) and Lovegrove (2000) noted the prevalence of mammals undergoing torpor in the Southern Hemisphere. Why so many southern mammals species show torpor is not clear. Unpredictable environments due to El Niño events are often suggested. However historical processes like the sorting of species through immigration may also provide important insight into the geographic distribution of torpor in mammals. 


\section{Teiid lizards in Europe}

The presence of teiid lizards in the European Cenozoic is very brief (only one Mammalian standard level, MP17 in the late Eocene). Apart from the remains described here, Augé (2005) has described the species Brevisaurus smithi, a putative teiid. Brizuela (2010) mentions several characters (e.g. uniform dentition, presence of only the anterior narial support) that deviate from those of extant teiids. Thus, further studies are needed in order to confirm this assignment. These teiid lizards were able to gain a foothold in Europe, but apparently, they neither diversified nor persisted in the recipient biota (Fig. 12). So, it would be interesting to examine the circumstances (physical and biological) surrounding this failure. The late Eocene in Europe corresponded to a progressive drop in temperature (Zachos et al. 2001; Mosbrugger et al. 2005; Liu et al. 2009) initiated during the middle Eocene and continued after the Eocene/Oligocene boundary. Despite deceasing temperature, the late Eocene in Europe is characterised by a rich and diverse lizard fauna (Augé and Smith 2009). Samplingcorrected lepidosaurian diversity curves (Smith et al. 2006; Cleary et al. 2018) confirm that Europe and North America have high generic diversity in the late Eocene and diversity in Europe is at its maximum during this period (Cleary et al. 2018). At that time, Europe was an archipelago, relatively isolated from the nearest continents, although episodic faunal exchanges are still possible, in particular with Africa and Asia.

Abiotic factors, like the temperature drop during the late Eocene period, may explain change in the distribution of vertebrate and could have limited the survival of many species particularly subtropical lizards like Teiidea. Extant teiids have high body temperatures (Schall 1977; Casas-Andreu and Currola-Hidalgo 1993) and they are poorly diversified or absent in temperate zones and at high elevations. However, several thermophilic taxa (iguanids, gekkonids, cordylids, helodermatids, varanids and boids, Rage 2013) persisted throughout the late Eocene in the Phosphorites du Quercy and temperatures certainly remained rather high.

Turnover of lizard species is rather low during the late Eocene ( 0.18 between MP17 and MP18) but it becomes greater than $0.50(0.67)$ across the Eocene/ Oligocene boundary (Table 2). In addition, the per species change in species richness (as defined by Sax et al. 2005, see legend Table 2) over the late Eocene (MP17MP20) is low ( -0.19 between MP17 and MP18). In stark contrast, the variation (decline) in species richness $(-0.44)$ across the Eocene/Oligocene boundary is important. The minimum bound on per species change is -1 , the point at which $100 \%$ of the initial species richness is lost; the maximum bound is potentially unlimited but a positive value denotes an increase in species richness. Actually, a severe extinction event affected the lizard fauna across the Eocene/Oligocene boundary
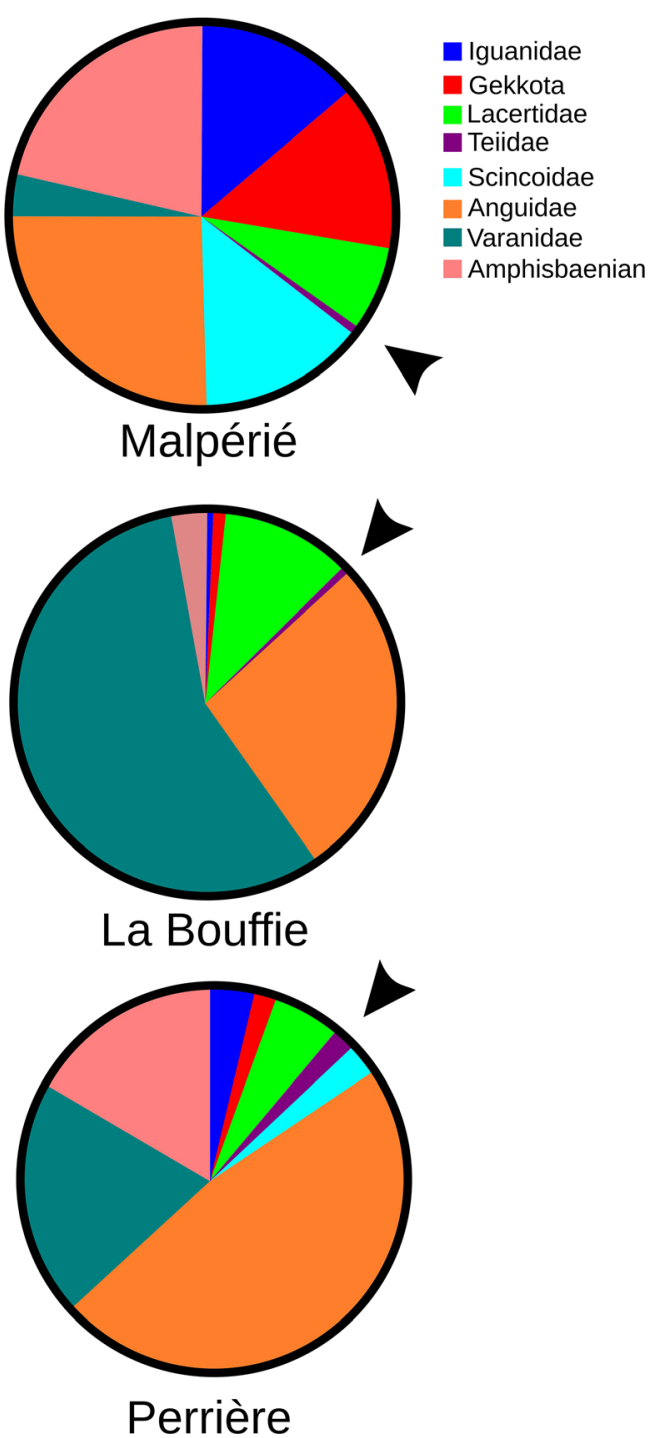

Fig. 12 Percentage of teiid specimens in the MP17 lizard fauna from the Phosphorites du Quercy: Perrière B, 2\% (total number of specimens: 109); La Bouffie, $1 \%$ (total number of specimens 220); Malpérié, $1 \%$ (total number of specimens 169). It may be added that two other localities from the MP17 level of the Phosphorites du Quercy have yielded no teiid remains (Aubrelong 2 and Les Pradigues)

(Grande Coupure, Stehlin 1909) but disappearance of teiids in Europe largely predates this event and it occurs during a period of low biotic turnover (at least for lizards).

Biotic interactions are the other processes that structure the distribution and presence of species. For example, Losos (2009) provided strong evidence that extant sympatric anoles (Iguania) interact ecologically in the West Indies. Usually, it is difficult to separate the resistance of biotic communities from resistance determined by abiotic environments (Rejmánek 1999). Nevertheless, the competition model may be helpful here: it postulates that communities are saturated and are structured by competition processes, and that competition often leads to extinction of subordinate species (Simberloff 1981). 
Table 2 Apparent turnover and per species change in species richness in several standard levels of the European Paleogene (MP17-MP20, late Eocene; MP21-22 earliest early Oligocene; GC, Eocene-Oligocene Grande Coupure). The per species change in species richness over some specified time interval is calculated as $\square \mathrm{S}=(\mathrm{Sf}-\mathrm{So}) / \mathrm{So}$, where So and $\mathrm{Sf}$ are the initial and final number of species, respectively. Apparent turnover of species is calculated as the sum of species appearances and extinctions divided by the sum of initial and final species richness

\begin{tabular}{lccccc}
\hline Standard levels & Species richness (S) & Extinction & Appearance & $\begin{array}{c}\text { Per species } \\
\text { change in S }\end{array}$ & $\begin{array}{c}\text { Apparent turnover } \\
\text { MP 21-22 }\end{array}$ \\
MP 19-20 & 10 & 14 & 5 & -0.44 & 0.05 \\
MP 18 & 18 & 1 & 2 & 0.05 & 0.08 \\
MP 17 & 17 & 6 & 1 & 0.19 & 0.23 \\
MP 16 & 21 & 3 & 8 & - & - \\
\hline
\end{tabular}

A widely accepted definition of competition is a negative interaction between two species of the same trophic level that occurs as a result of shared use of the same resources (Connell 1983). The late Eocene (MP17-MP19) localities of the Phosphorites du Quercy have yielded very diverse assemblages of lizards. Thus, the trophic niche occupied by lizards may have been near saturation at that time, exacerbating the effects of competition.

Two potential competitors of teiids have been present for a long time in the European Eocene: lacertid lizards and a purported Varanidae, the genus Palaeovaranus (ex-Necrosaurus, Georgalis 2017). Lacertid and teiid lizards are highly active animals with high temperatures and a rather diversified diet. According to Vitt and Pianka (2004), teiids appear to be ecological couterparts of lacertids and the Bauplan of teiids is similar to that of many lacertids. The Eocene lacertid Plesiolacerta lydekkeri is present in the same localities (Čerňanský and Augé 2013) as the teiid described here and their sizes are similar. Moreover, Vitt and Pianka (2004) state that varanids are active and voracious predators, resembling in many ways some of the extant large teiids like Ameiva. The genus Palaeovaranus, a purported varanid lizard, is also present in the Eocene localities that yielded teiid lizards (Augé 2005). Palaeovaranus shows large recurved, pointed teeth with basal fluting that may reveal the presence of plicidentine, which is a derived character of varanid lizards. The size of Palaeovaranus and Plesiolacerta is comparable to that of the Eocene teiid.

Most often, negative abundance correlations between two taxa are regarded as the result of competitive exclusion. Competitive explanations have traditionally been used by palaeontologists to account for the extinction of several groups. In many cases, these explanations have been questioned by a close examination of the fossil record (e.g. Raup 1982; Benton 1983, 1987; Miller 2000; Augé 2007). A test has been proposed to highlight the purported negative abundance relations between two taxa over geological periods, the so called double-wedge pattern (Benton 1996; Sepkoski 1996). However, it cannot be used here due to the brief presence of teiids in the European Eocene. In the absence of direct information, some evidence of competition between two groups may come from their complementary distribution (Diamond 1975). It is worth noting that during the Cenozoic era, teiids never co-occurred with lacertids or Varanoidea, except in the European Eocene. Moreover, as recognised by Holt et al. (2005), if the ancestral habitat of an invading species is different from its new habitat (cf. ecological niche sensu Hutchinson 1978 and Holt and Gaines 1992), extinction of this species is probable. Abiotic conditions in Europe and South America during the Eocene may have been comparable (subtropical climate and relative isolation from other continents) but their biotic environments were clearly different as far as lizard diversity is concerned: the MP17 European locality of Malpérié has yielded 13 lizard families or subfamilies. In South America, the only confirmed Eocene lizard is the tupinambinae teiid Lumbrerasaurus (Brizuela and Albino 2016), although there is a rich and diverse fauna of lizards mention in Itaborai (Brazil) which has yet to be published and which would include an Iguania incertae sedis, a gekkonid, two "Scincomorpha" incertae sedis, a Teiidae, and two Anguimorpha incertae sedis (Carvhalo 2001). If this is confirmed, then in the Eocene of South America, there would have been at least 5 lizard families or subfamilies, still fewer than in the European Eocene.

An old hypothesis (Elton 1958) about the relationship between the diversity and the relative invasibility of a region is that more diverse communities should be more resistant to invasion (Case 1990; Tilman 2004). To be fair, many observational studies show that more diverse extant communities support more invaders (e.g. Rejmánek 1996; Wiser et al. 1998) and recent studies that quantified species richness of geographic regions have often found an increase in species diversity (Sax et al. 2002; Sax and Gaines 2003). On the other hand, Kinlan and Hastings (2005) found a strong relation between the inability of a species to increase from low density (Allee effects) and the importance of long-distance dispersal. The probability that teiid lizards cross significant 
oceanic barriers and arrive in Europe is certainly low. So, the number of successful invasions is probably very limited and presumably those invasions are achieved by just a few individuals. The success of recent deliberate introductions within a region mostly depends on the number of introduction and the number of introduced individuals (Green 1997; Levine 2000; D'Antonio et al. 2001). Actually, the number of teiid specimens collected in the localities from the Phosphorites du Quercy is very low and represents only a minute fraction of the lizard specimens yielded by these localities (Fig. 12). Allee effects encompass all aspects of the processes that result in negative population growth rates at low density (Allee 1931): for example, a small number of individuals may fail to encounter mates simply by chance or be wiped out by stochastic environmental fluctuations. In sum, several mechanisms may explain the rapid disappearance of teiid lizards in Europe: competition; demographic processes resulting from the low number of invaders and more questionably, the possible existence of a "species capacity or carrying capacity": species richness in a given area could be bounded at some equilibrium point (McArthur and Wilson 1967).

\section{Conclusion}

Biotic invasions are a pervasive component of present global change and have important consequences for the conservation of biological diversity. It is often argued from the fossil record of biotic interchange that the less diverse region (South America in the case of Eocene fossil lizards) is typically more invaded by species than the more diverse region (Europe, see Vermeij 1991). Arrival of South American teiids in the European Eocene is clearly a departure from this pattern as lizard taxa in Europe outnumbered those in South America.

$>$ Recent surveys of biotic interchanges suggest that a positive relationship exists between the number of native species in a region and the number of invaders whereas past biotic exchanges over geologic times support negative effects of diversity on invasibility. How to reconcile these two disparate observations? One possibility is that, for extant biotic interchanges, there has not been enough time since the recent invasions for extinction to occur and that present communities carry an extinction debt (Tilman et al. 1996) that will eventually be paid.

The brief presence of teiid lizards in the European Eocene (limited to the MP17 standard level) may illustrate this process. Their rapid disappearance from the European fossil record may be tentatively ascribed to ecological and demographical mechanisms that regulate biodiversity: arrival of teiids in Europe was probably achieved by few individuals; biotic interactions (e.g. competition with Lacertidae, Varanoidea and even Helodermatidae) certainly prevented them from diversifying and expanding their range in the new region. In addition, the inability of European teiids to increase from low densities may have been reinforced by demographic processes (Allee effects). So, the eventual fate of this taxon is to decline in numbers and distribution and eventually to disappear.

As a last point, further support for our hypothesis may come from the discovery of new teiid remains from the Eocene of Europe as well as from the Paleogene of Africa, the purported pathway between Europe and South America.

Acknowledgements It is a pleasure to thank P. Loubry and L. Cazes for the photographs. We are most indebted to J-C Rage for access to the fossil material and constructive discussion. We are grateful to Krister Smith and Andrej Čerňanský for their helpful reviews. We acknowledge the assistance provided by the MNHN and the director of the herpetological collections, NourEddine Jalil. For assistance with extant specimens, we would like to thank the Laboratoire d'Anatomie comparée du Muséum and in particular S. Bailon. We are also particularly grateful to K. Smith who, for the first time, identified teiid remains in the material from the Phosphorites du Quercy. We would like to thank M. Merlo and E. Verón (both CONICET-UNMdP) for they assisted with essential equipment and technical support respectively.

\section{Compliance with ethical standards}

Conflict of interest The authors declare that they have no conflict of interest.

\section{References}

Albino, A. M., \& Brizuela, S. (2014). First record of squamate reptiles from the Oligocene of South America. Alcheringa: Australasian Journal of Palaeontology, 38(3), 412-421.

Allee, W. C. (1931). Animal aggregations. A study in general sociology. Chicago: University of Chicago Press.

Angst, D., Buffetaut, E., Lécuyer, C., \& Amiot, R. (2013). « Terror birds » (Phorusrhacidae) from the Eocene of Europe imply trans-Tethys dispersal. PLoS One, 8(11), e80357. https://doi.org/10.1371/ journal.pone.0080357.

Antoine, P.-O., Marivaux, L., Croft, D. A., Billet, G., Ganerød, M., Jaramillo, C., Martin, T., Orliac, M. J., Tejada, J., Altamirano, A. J., Duranthon, F., Fanjat, G., Rousse, S., \& Salas-Gismondi, R. (2012). Middle Eocene rodents from Peruvian Amazonia reveal the pattern and timing of caviomorph origins and biogeography. Proceedings of the Royal Society of London B, 279, 1319-1326.

Arnault, S. (1987). Tropical Atlantic geostrophic currents and ship drifts. Journal of Geophysal Research, 92, 5076-5088.

Augé, M. L. (2003). Lacertilian faunal change across the PaleoceneEocene boundary in Europe. In S.L. Wing, P. Gingerich, B. Schmitz, \& E. Thomas (Eds.) Causes and Consequences of globally warm climates in the Early Paleogene (pp 441-453). Boulder, Colorado, Geological Society of America Special Paper 369. 
Augé, M. L. (2005). Evolution des lézards du Paléogène en Europe. Paris, Mémoires du Muséum National d' Histoire Naturelle, 192, $369 \mathrm{p}$.

Augé, M. L. (2007). Past and present distribution of iguanid lizards. Arquivos do Museu Nacional, Rio Janeiro, 65(4), 403-416.

Augé, M. L., \& Guével, B. (2018). New varanid remains from the Miocene (MN4-MN5) of France: inferring fossil lizard phylogeny from subsets of large morphological data sets. Journal of Vertebrate Paleontology. https://doi.org/10.1080/02724634.2017.1410483.

Augé, M. L., \& Smith, R. (2009). An assemblage of early Oligocene lizards (Squamata) from the locality of Boutersem (Belgium), with comments on the Eocene-Oligocene transition. Zoological Journal of the Linnean Society, 155, 148-170.

Benton, M. J. (1983). Large-scale replacements in the history of life. Nature, 302, 16-17.

Benton, M. J. (1987). Progress and competition in macroevolution. Biological Reviews, 62, 305-338.

Benton, M. J. (1996). On the nonprevalence of competitive replacement in the evolution of tetrapods. In A. D. Jablonski, D. Erwin, \& J. Lipps (Eds.) Evolutionary Paleobiology (pp. 185-210). Chicago: University of Chicago Press.

Bochaton, C., Boistel, R., Grouard, S., Ineich, I., Tresset, A., \& Bailon, S. (2017). Evolution, diversity and interactions with past human populations of recently extinct Pholidoscelis lizards (Squamata; Teiidae) from the Guadeloupe Islands (French West-Indies). Historical Biology. https://doi.org/10.1080/08912963.2017. 1343824.

Bolet, A., \& Augé, M. (2014). A new miniaturized lizard from the late Eocene of France and Spain. The Anatomical Record, 297, 505-515.

Bolet, A., \& Evans, S. E. (2013). Lizards and amphisbaenians (Reptilia, Squamata) from the late Eocene of Sossís (Catalonia, Spain). Palaeontologia Electronica, 16(1), 8A 23.

Bonaparte, C. L. (1831). Saggio d'una distribuzione metodica degli Animali Vertebrati. Giornale Arcadico di Scinze Lettere ed Arti, $49,1-76$.

Bourles, B., Molinari, R. L., Johns, E., Wilson, W. D., \& Leaman, K. D. (1999). Upper layer currents in the western tropical North Atlantic (1989-1991). Journal of Geophysical Research, 104(C1), 13611375.

Bradshaw, D. (2003). Vertebrate ecophysiology (287p). Cambridge: Cambridge University Press.

Brizuela, S. (2010). Los lagartos continentales fosiles de la Argentina (Excepto Iguania). Tesis Doctoral, Facultad de Ciencias Naturales y Museo Universidad National de La Plata.

Brizuela, S., \& Albino, A. M. (2004). The earliest Tupinambis teiid from South America and its palaeoenvironmental significance. Journal of Herpetology, 38, 113-119.

Brizuela, S., \& Albino, A. M. (2010). Variationes dentarias en Tupinambis merianae (Squamata: Teiidae). Cuadernos de Herpetología, 24, 5-16.

Brizuela, S., \& Albino, A. M. (2016). First Tupinambinae teiid (Squamata, Teiidae) from the Palaeogene of South America. Historical Biology, 28, 571-581.

Caldwell, M. W., Budney, L. A., \& Lamoureux, D. O. (2003). Histology of tooth attachment tissues in the Late Cretaceous mosasaurid Platecarpus. Journal of Vertebrate Paleontology, 23, 622-630.

Calsbeek, R., \& Smith, T. B. (2003). Ocean currents mediate evolution in island lizards. Nature, 426, 552-555.

Camp, C. L. (1923). A classification of the lizards. Bulletin of the American Museum of Natural History, 48, 289-481.

Carranza, S., \& Arnold, E. N. (2003). Investigating the origin of transoceanic distributions: Mtdna shows Mabuya lizards (Reptilia, Scincidae) crossed the Atlantic twice. Systematics and Biodiversity, 1(2), 275282.

Carranza, S., \& Arnold, E. N. (2006). Systematics biogeography and evolution of Hemidactylus geckos (Reptilia: Gekkonidae) elucidated using mitochondrial DNA sequences. Molecular Phylogenetics and Evolution, 38, 531-545.

Carranza, S., Arnold, E. N., Mateo, J. A., \& Lopez-Jurado, L. F. (2000). Long-distance colonization and radiation in gekkonid lizards, Tarentola (Reptilia: Gekkonidae), revealed by mitochondrial DNA sequences. Proceedings Royal Society of London, B Biol., 267, 637649.

Carton, J., \& Katz, E. (1990). Estimates of the zonal slope and seasonal transport of the Atlantic North Equatorial Countercurrent. Journal of Geophysical Research, 95, 3091-3100.

Carvalho, A.B. (2001). Estudo taxonomico dos lagartos fosseis (Lepidosauria: Squamata) da Bacia de Sao José de Itaborai (Paleoceno), Estado do Rio de Janeiro. Master Disertation. Museu Nacional/UFRJ, Universidade Federal do Rio de Janeiro, Rio de Janeiro.

Casas-Andreu, G., \& Currola-Hidalgo, M. A. (1993). Comparative ecology of two species of Cnemidophorus in central Jalisco, Mexico. In J. W. Wright \& L. J. Vitt (Eds.) Biology of whiptail lizards (genus Cnemidophorus) (pp. 133-150). Norman: Oklahoma Museum National History.

Case, T. J. (1990). Invasion resistance arises in strongly interacting species-rich model competitive systems. Proceedings of the National Academy of Science USA, 87, 9610-9614.

Censky, E. J., Hodge, K., \& Dudley, J. (1998). Over-water dispersal of lizards due to hurricanes. Nature, 395, 556

Čerňanský, A., \& Augé, M. L. (2013). New species of the genus Plesiolacerta (Squamata: Lacertidae) from the upper Oligocene (MP28) of southern Germany and a revision of the type species Plesiolacerta lydekkeri. Palaeontology, 56(1), 79-94.

Čerňanský, A., Augé, M. L., \& Rage, J. C. (2015). A complete mandible of a new Amphisbaenian reptile (Squamata, Amphisbaenia) from the late middle Eocene (Bartonian, MP16) of France. Journal of Vertebrate Paleontology, 35. https://doi.org/10.1080/02724634. 2014.902379.

Čerňanský, A., Klembara, J., \& Müller, J. (2016). The new rare record of the late Oligocene lizards and amphisbaenians from Germany and its impact on our knowledge of the European terminal Paleogene. Palaeobiodiversity and Palaeoenvironments, 96(4), 559-587. https://doi.org/10.1007/s12549-015-0226-8 .

Cleary, T. J., Benson, R. B., Evans, S. E., \& Barrett, P. M. (2018). Lepidosaurian diversity in the Mezosoic-Palaeogene: the potential roles of sampling biases and environmental drivers. Royal Society Open Science, 5, 171830. https://doi.org/10.1098/rsos.171830.

Codrea, V. A., Venczel, M., \& Salomon, A. (2017). A new family of teiioid lizards from the Upper Cretaceous of Romania with notes on the evolutionary history of early teiioids. Zoologial Journal Linnean Society, 20, 1-15.

Connell, J. H. (1983). On the prevalence and relative importance of interspecific competition: evidence from field experiments. American Naturalist, 122, 661-696.

Conrad, J. L. (2008). Phylogeny and systematics of Squamata (Reptilia) based on morphology. Bulletin of the American Museum of Natural History, 310, 1-182.

Cossins, A. R., \& Barnes, B. (1996). Southern discomfort. Nature, 382, 582-583.

D'Antonio, C., Meyerson, L. A., \& Denslow, J. (2001). Exotic species and conservation. In M. E. Soulé \& G. H. Orians (Eds.) Conservation biology: priorities for the next decade (pp. 59-80). Washington, DC: Island Press.

De Oliveira, F. B., Molina, E. C., \& Marroig, G. (2009). Paleogeography of the South Atlantic: a route for primates and rodents into the New World. In P. A. Garber, A. EstradaJ. C. Bicca-Marques, E. W. Heymann (Eds.) South American primates, developments in primatology, progress and prospects (pp. 55-68). Berlin: Springer Science. 
Deacon, G. E. R. (1933). A general account of the hydrology of the South Atlantic Ocean. Discovery Reports, 7, 171-238.

Deacon, G. E. R. (1937). The hydrology of the Southern Ocean. Discovery Reports, 15, 3-122.

Delsuc, F., Catzeflis, F. M., Stanhope, M., \& Douzery, E. J. (2001). The evolution of armadillos, anteaters and sloths depicted by nuclear and mitochondrial phylogenies: implications for the status of the enigmatic fossil Eurotamandua. Proceedings of the Royal Society of London B, 268, 1605-1615.

Denton, R. K., \& O’Neill, R. C. (1995). Prototeius stageri, gen. et sp. nov., a new teiid lizard from the Upper Cretaceous Marshalltown Formation of New Jersey, with a preliminary phylogenetic revision of the Teiidae. Journal of Vertebrate Paleontology, 15, 235-253.

Dessem, D. (1985). Ontogenetic changes in the dentition and diet of Tupinambis (Lacertilia: Teiidae). Copeia, 1985, 245-247.

Diamond, J. M. (1975). Assembly of species communities. In M. L. Cody \& J. M. Diamond (Eds.) Ecology and evolution of communities (pp. 342-444). Cambridge: Belknap Press.

Eagles, G. (2007). New angles on South Atlantic opening. Geophysical Journal International, 166, 353-361.

Edmund, G. (1960). Tooth replacement phenomena in the lower vertebrates. Royal Ontario Museum Life Science Diversity, Contribution, 52, 1-190.

Elton, C. S. (1958). The ecology of invasions by animals and plants. London: Methuen.

Estes, R. (1983). Sauria terrestria, Amphisbaenia. In O. Kuhn \& P. Wellnhofer (Eds.) Handbuch der Paläoherpetologie, Teil 10A (249p). Stuttgart: G. Fischer Verlag.

Estes, R., \& Williams, E. E. (1984). Ontogenetic variation in the molariform teeth of lizards. Journal of Vertebrate Paleontology, 4(1), 96-107.

Estes, R., de Queiroz, K., \& Gauthier, J. (1988). Phylogenetic relationships within Squamata. In R. Estes \& G. Pregill (Eds.) Phylogenetic relationships of the lizard families (pp. 119-281). Stanford: Stanford University Press.

Evans, S.E. (2008). The skull of lizards and tuatara. In C. Gans, A.S. Gaunt, K. Adler (Eds.) Biology of the Reptilia, Vol 20, Morphology H, The Skull of Lepidosauria (pp. 1-347). Totnes: Society for the study of Amphibians and Reptiles.

Ezcurra, M. D., \& Agnolin, F. L. (2012). A new global palaeobiogeographical model for the Late Mesozoic and Early Tertiary. Systematic Biology, 61(4), 553-566.

Fitzinger, L.J. (1826). Neue Classification der Reptilien nach ihren natürlichen Verwandtschaften. Nebst einer Verwandtschafts-tafel und einem Verzeichnisse der Reptilien-Sammlung des K. K. zoologischen Museum's zu Wien. Wien. 66 pp.

Folie, A. (2006). Evolution des amphibiens et squamates de la transition Crétacé-Paléogène en Europe: les faunes du Maastrichtien du Bassin de Hateg (Roumanie) et du Paléocène du Bassin de Mons (Belgique). Brussels, Thèse de doctorat, Université libre de Bruxelles, Faculté des Sciences, 274p.

Folie, A., \& Codrea, V. (2005). Lissamphibians and squamates from the Maastrichtian of Hateg Basin, Romania. Acta Palaeontologica Polonica, 50(1), 57-71.

Fratantoni, D. M. (2001). North Atlantic surface circulation during the 1990's observed with satellite-tracked drifters. Journal of Geophysical Research, 106(C10), 22067-22093.

Fratantoni, D. M., Johns, W. E., Townsend, T. L., \& Hurlburt, H. E. (2000). Low-latitude circulation and mass transport pathways in a model of the tropical Atlantic Ocean. Journal of Physical Oceanography, 20, 1944-1966.

Frazzetta, T. H. (1962). A functional consideration of cranial kinesis in lizards. Journal of Morphology, 111, 287-320.

Gamble, T., Bauer, A. M., Collis, G. R., Greenbaum, E., Jackman, T. R., Vitt, L. J., \& Simons, A. M. (2011). Coming to America: multiple origins of New World geckos. Jounal Evolutionary Biology, 24, 231-244.

Gauthier, J. A. (1984). A cladistic analysis of the higher systematic categories of the Diapsida. Berkeley, Ph.D. Thesis, University of California.

Gauthier, J. A., Kearney, M., Maisano, J. A., Rieppel, O., \& Behlke, A. D. (2012). Assembling the squamate tree of life: perspectives from the phenotype and the fossil record. Bulletin of the Peabody Museum of Natural History, 53, 3-308.

Georgalis, G. L. (2017). Necrosaurus or Palaeovaranus? Appropriate nomenclature and taxonomic content of an enigmatic fossil lizard clade (Squamata). Annales de Paleontologie. https://doi.org/10. 1016/j.annpal.2017.10.001.

Gèze, B. (1938). Contribution à la connaissance des Phosphorites du Quercy. Bulletin de la Société Géologique de France, 8(1-2), 123-146.

Gheerbrant, E., \& Rage, J.-C. (2006). Paleobiogeography of Africa: how distinct from Gondwana and Laurasia? Palaeogeography Palaeoclimatology Palaeoecology, 241, 224-246.

Gheerbrant, E., Abrial, C., \& Cappetta, H. (1997). Nouveaux sites à microvertébrés continentaux du Crétacé terminal des Petites Pyrénées (Haute-Garonne et Ariège, France). Geobios Mémoire Spécial, 20, 257-269.

Gittenberger, E. (2012). Long-distance dispersal of molluscs: 'Their distribution at first perplexed me much'. Journal of Biogeography, 39, $10-11$.

Giugliano, L. G., Collevatti, R. G., \& Colli, G. R. (2007). Molecular dating and phylogenetic relationships among Teiidae (Squamata) inferred by molecular and morphological data. Molecular Phylogeny and Evolution, 45, 168-179.

Goicoechea, N., Frost, D. R., De la Riva, I., Pellegrino, K. C., Sites, J., Rodrigues, M. T., \& Padial, J. M. (2016). Molecular systematics of teioid lizards (Teioidea / Gymnophthalmoidea: Squamata) based on the analysis of 48 loci under tree-alignment and similarity-alignment. Cladistics, 32(6), 624-671.

Goloboff, P. J., Farris, J., \& Nixon, K. (2008). TNT, a free program for phylogenetic analysis. Cladistics, 24, 1-13.

Green, R. E. (1997). The influence of numbers released on the outcome of attempts to introduce exotic bird species to New Zealand. The Journal of Animal Ecology, 66, 25-35.

Guillerme, T., \& Cooper, N. (2016). Effects of missing data on topological inference using a total approach. Molecular Phylogenetics and Evolution, 94, 146-158.

Haq, B. U. (1981). Paleogene paleoceanography. Early Cenozoic oceans revisited. Oceanologica Acta, 4(suppl), 71-82.

Harvey, M. B., Ugueto, G. N., \& Gutberlet, R. L. (2012). Review of Teiid morphology with a revised taxonomy and phylogeny of the Teiidae (Lepidosauria: Squamata). Zootaxa, 3459, 1-156.

Hisard, P. (1980). Observation de réponses de type "El Niño" dans l'Atlantique tropical oriental du Golfe de Guinée. Oceanologica Acta, 3, 69-78

Hoffstetter, R. (1972). Relationships, origins, and history of the ceboid monkeys and caviomorph rodents: a modern reinterpretation. Evolutionry Biology, 6, 322-347.

Hoffstetter, R. (1980). Origin and deployment of New World monkeys emphasizing the southern continents route. In R. L. Ciochon \& A. B. Chiarelli (Eds.) Evolutionary biology of the New World monkeys and continental drift (pp. 103-122). New York: Plenum Press.

Hoffstetter, R., \& Gasc, J. (1969). Vertebrae and ribs of modern reptiles. In C. Gans (Ed.) Biology of the Reptilia 1, Morphology A, (pp. 201310). London: Academic Press.

Holt, R., \& Gaines, M. (1992). The analysis of adaptation in heterogeneous landscapes: implications for the evolution of fundamental niches. Evolutionary Ecology, 6, 433-447.

Holt, R., Barfield, M., \& Gomulkiewicz, R. (2005). Theories of niche conservatism and evolution. In D. Sax, J. Stachowicz, \& S. Gaines 
(Eds.) Species invasions, insights into ecology, evolution and biogeography (pp. 259-290). Sunderland: Sinauer Associates.

Houle, A. (1999). The origin of platyrrhines: an evaluation of the Antarctic scenario and the floating island model. American Journal of Physical Anthropology, 109, 541-559.

Hutchinson, G. E. (1978). An introduction to population ecology. New Haven: Yale University Press.

Kappeler, P. M. (2000). Lemur origins: rafting by groups of hibernators? Folia Primatologica, 71, 422-425.

Kinlan, B. P., \& Hastings, A. (2005). Rates of population spread and geographic range expansion. In D. F. Sax, J. J. Stachowicz, \& S. D. Gaines (Eds.) Species invasions. Insights into ecology, evolution and biogeography (pp. 381-419). Sunderland: Sinauer Associates.

Klingenberg, C. P., \& Gidaszewski, N. (2010). Testing and quantifying phylogenetic signals and homoplasy in morphometric data. Systematic Biology, 59(3), 245-261.

Kluge, A.G., \& Nussbaum, R.A. (1995). A review of AfricanMadagascan gekkonid lizard phylogeny and biogeography (Squamata). Miscellaneous Publication Museum Zoology University Michigan, 183, 1-20.

Kosma, R. (2004). The dentitions of recent and fossil scincomorphan lizards (Lacertilia, Squamata)—systematics, functional morphology, paleoecology. PhD Dissertation, University of Hannover, Germany.

Lavers, C. (2000). Why elephants have big ears: nature's engines and the order of life. London: Gollancz.

Lenz, O. K., Wilde, V., \& Riegel, W. (2016). ENSO and solar-driven subMilankovitch cyclicity in the Palaeogene pollen records from Eocene Lake Messel, Germany. Journal of the Geological Society, 174(1), 110-128 greenhouse world; high-resolution.

Levine, J. M. (2000). Species diversity and biological invasions: relating local process to community patterns. Science, $288,852-854$.

Lim, B. K. (2009). Review of the origins and biogeography of bats in South America. Chiroptera Neotropical, 15(1), 391-410.

Linder, H. P., Antonelli, A., Humphreys, A. M., Pirie, M. D., \& Wüest, R. O. (2013). What determines biogeographical ranges? Historical wanderings and ecological constraints in the danthonioid grasses. Journal of Biogeography, 40(5), 821-834.

Liu, Z., Pagani, M., Zinniker, D., Deconto, R. M., Huber, M., Brinkhuis, H., Shah, S. R., Leckie, R. M., \& Pearson, A. (2009). Global cooling during the Eocene-Oligocene climate transition. Science, 323, $1187-1190$.

Longrich, N. R., Bhullarb, B.-A. S., \& Gauthier, J. A. (2012). Mass extinction of lizards and snakes at the Cretaceous-Paleogene boundary. PNAS, 109(52), 21396-21401.

Losos, J. B. (2009). Lizards in an evolutionary tree: ecology and adpative radiation of anoles (507pp). Oakland, California: University of California Press.

Lovegrove, B. G. (2000). The zoogeography of mammalian basal metabolic rate. American Naturalist, 156(2), 201-219.

Maddison, W.P., \& Maddison, D.R. (2016). Mesquite: a modular system for evolutionary analysis. Version 3.10 HTTP://mesquiteproject.org.

Makádi, L. (2006). Bicuspidon aff. hatzegiensis Squamata: Scincomorpha: Teiidae from the Upper Cretaceous Csehbánya Formation Hungary, Bakony Mts. Acta Geologica Hungarica, 49(4), 373-385.

Makádi, L. (2013a). The first known chamopsiid lizard (Squamata) from the Upper Cretaceous of Europe (Csehbánya Formation; Hungary, Bakony Mts). Annales de Paleontologie, 99(2013), 261-274.

Makádi, L. (2013b). A new polyglyphanodontine lizard (Squamata: Borioteiioidea) from the Late Cretaceous Iharkút locality (Santonian, Hungary). Cretaceous Research, 46, 166-176.

Malan, A. (1996). The origins of hibernation: a reappraisal. In F. Geiser, A. J. Hulbert, \& S. C. Nicol (Eds.) Adaptation to the cold (pp. 1-6). Armidal: University of New England Press.
Marshall, L. G., Webb, S. D., Sepkoski, J. J., \& Raup, D. M. (1982). Mammalian evolution and the great American interchange. Science, 215(4538), 351-357.

Martin, R. D. (1972). Adaptive radiation and behaviour of Malagasy lemurs. Philosophical Transactions of the Royal Society of London B, 264, 295-352.

Matthew, W. D. (1915). Climate and evolution. Annals of the New York Academy of Sciences, 24, 171-318.

Mayr, G., Alvarenga, H., \& Mourer-Chauviré, C. (2011). Out of Africa: fossils shed light on the origin of the hoatzin, an iconic Neotropic bird. Naturwissenschaften, 98, 961-966.

Mc Cartney, M. S. (1977). Subantarctic mode water. In M. Angel (Ed.) A voyage of discovery (pp. 103-119). Oxford: Pergamon Press.

Mc Nab, K. (2002). The physiological ecology of vertebrates (576p). Ithaca: Cornell University Press.

McArthur, R. H., \& Wilson, E. O. (1967). The theory of islands biogeography. Princeton: Princeton University Press.

Miller, A.I. (2000). Conversations about Phanerozoic global diversity. In D. Erwin, S. Wing (Eds.) Deep time: paleobiology's perspective. Paleobiology, 26, 53-73.

Mooney, H. A., \& Cleland, E. E. (2001). The evolutionary impact of invasive species. PNAS, 98, 5446-5451.

Mosbrugger, V., Utescher, T., \& Dilcher, D. L. (2005). Cenozoic continental climatic evolution of Central Europe. PNAS, 102(42), 14964 14969.

Mourer-Chauviré, C. (1999). Les relations entre les avifaunes du Tertiaire inférieur d'Europe et d'Amérique du Sud. Bulletin Société Géologique de France, 170(1), 85-90.

Mourer-Chauviré, C., Tabuce, R., Mahboubi, M., Adaci, M., \& Bensalah, M. (2011). A Phororhacoid bird from the Eocene of Africa. Naturwissenschaften, 98, 815-823.

Nydam, R. L. (2013). Squamates from the Jurassic and Cretaceous of North America. In J. D. Gardner, \& R. L. Nydam (Eds.) Mesozoic and Cenozoic Lissamphibian and Squamate assemblages of Laurasia. Palaeobiodiversity Palaeoenvironments, 93(4), 535-565.

Nydam, R. L., \& Cifelli, R. (2002). Lizards from the Lower Cretaceous (Aptian-Albian) Antlers and Clovery formations. Journal of Vertebrate Paleontology, 22(2), 286-298.

Nydam, R. L., Eaton, J. G., \& Sankey, J. (2007). New taxa of transversely-toothed lizards (Squamata: Scincomorpha) and new information on the evolutionary history of 'teiids'. Journal of Paleontology, 81(3), 538-549.

Oelrich, T. M. (1956). The anatomy of the head of Ctenosaura pectinata (Iguanidae). Miscellaneous Publication of the Museum of Zoology, University of Michigan, 94, 1-122.

Oppel, M. (1811). Die Ordnungen, Familien und Gattungen der Reptilien als Prodrom einer Naturgeschichte derselben (86p). München: J. Lindauer.

Parrish, J. T. (1993). The palaeogeography of the opening South Atlantic. In W. George \& R. Lavocat (Eds.) The Africa-South America connection (pp. 8-27). Clarendon Press: Oxford.

Peterson, R. G., \& Stramma, L. (1991). Upper-level circulation in the South Atlantic Ocean. Progress in Oceanography, 26(1), 1-73.

Pianka, E. R., \& Vitt, L. J. (2003). Lizards, windows to the evolution of diversity. Berkeley: University of California Press.

Poux, C., Chevret, P., Huchon, D., De Jong, W., \& Douzery, E. (2006). Arrival and diversification of Caviomorph rodents and Platyrrhine Primates in South America. Systematic Biology, 55(2), 228-244.

Presch, W. (1974). A survey of the dentition of the macroteiid lizards (Teiidae, Lacertilia). Herpetologica, 30, 344-349.

Presch, W. (1980). Evolutionary history of the south American microteiid lizards (Teiidae: Gymnophthalminae). Copeia, 1980(1), 36-56.

Pyron, A. R. (2015). Post-molecular systematics and the future of phylogenetics. Trends in Ecology \& Evolution, 30(7), 384-389. 
Pyron, R. A., Burbrink, F. T., \& Wiens, J. J. (2013). A phylogeny and revised classification of Squamata, including 4.161 species of lizards and snakes. BMC Evolutionary Biology, 13, 93.

Quadros, A. B., Chafrat, P., \& Zaher, H. (2018). A new teiid lizard of the genus Callopites Gravenhorst, 1838 (Squamata, Teiidae), from the Lower Miocene of Argentina. Journal of Vertebrate Paleontology. https://doi.org/10.1080/02724634.2018.1484754.

Rage, J.-C. (1999). Faunes à affinités sud-américaines dans le Paléogène d'Europe: état de la question. Allons-nous vers une nouvelle interprétation? Bulletin de la Société Géologique de France, $170(6), 951-954$.

Rage, J.-C. (2006). The lower vertebrates from the Eocene and Oligocene of the Phosphorites du Quercy (France): an overview. Strata, 1(13), 161-173.

Rage, J.-C. (2013). Mesozoic and Cenozoic squamates of Europe. In J. D. Gardner, \& R. L. Nydam (Eds.) Mesozoic and Cenozoic Lissamphibian and Squamate assemblages of Laurasia. Palaeobiodiversity Palaeoenvironments, 93(4), 517-534.

Rage, J.-C., \& Augé, M. (2010). Squamate reptiles from the middle Eocene of Lissieu (France). A landmark in the middle Eocene of Europe. Geobios, 43, 253-268.

Raup, D. M. (1982). Macroevolutionary implications of large body impacts. Geological Society of America, 14, 596.

Raxworthy, C. J., Forstner, M. R. J., \& Nussbaum, R. A. (2002). Chameleon radiation by oceanic dispersal. Nature, 415, 784-787.

Reeder, T. W., Townsend, T. M., Mulcahy, D. G., Noonan, B. P., Wood, P. L., Sites, J. W., \& Wiens, J. J. (2015). Integrated analyses resolve conflicts over squamate reptile phylogeny and reveal unexpected placements for fossil taxa. PLoS One, 10, e0118199.

Rees, W. J. (1965). The aerial dispersal of Mollusca. Proceedings Malacological Society London, 36, 269-282.

Rejmánek, M. (1996). Species richness and resistance to invasions. In G. H. Orians, R. Dirzo, \& J. H. Cushman (Eds.) Biodiversity and ecosystem processes in tropical forests (pp. 153-172). Berlin: Springer Verlag.

Rejmánek, M. (1999). Invasive plant species and invasible ecosystems. In O. T. Sandlund, P. J. Schel, \& A. Viken (Eds.) Invasive Species and Biodiversity Management (pp. 79-102). Dordrecht: Kluwer Academic Publishers.

Richardson, P. L., \& McKee, T. K. (1984). Average seasonal variation of the Atlantic equatorial currents from historical ship drifts. Journal of Physical Oceanography, 14, 1226-1238.

Roden, G. I. (1986). Thermohaline fronts and baroclinic flow in the Argentine Basin during the austral spring of 1984. Journal of Geophysical Research, 91, 5075-5093.

Rose, K. D. (2012). The importance of Messel for interpreting Eocene Holarctic mammalian faunas. In T. Lehmann, S. F. K. Schaal (Eds.) Messel and the terrestrial Eocene - Proceedings of the 22nd Senckenberg Conference. Palaeobiodiversity and Palaeoenvironments, 92(4), 631-647.

Sanmartin, I., Wanntrop, L., \& Winkworth, R. C. (2007). West wind drift revisited: testing for directional dispersal in the Southern Hemisphere using event-based tree fitting. Journal of Biogeography, 34(3), 398416.

Sansom, R. S. (2015). Bias and sensitivity in the placement of fossil taxa resulting from interpretations of missing data. Systematic Biology, 64(2), 256-266.

Sansom, R. S., \& Wills, M. A. (2013). Fossilization causes organisms to appear erroneously primitive by distorting evolutionary trees. Scientific Reports, 3, 2545. https://doi.org/10.1038/srep02545.

Sax, D. F., \& Gaines, S. D. (2003). Species diversity: from global decreases to local increases. Trends in Ecology \& Evolution, 18, 561566.

Sax, D. F., Gaines, S. D., \& Brown, J. H. (2002). Species invasions exceed extinctions on islands world-wide: a comparative study of plants and birds. American Naturalist, 160, 766-783.
Sax, D. F., Brown, J. H., White, E. P., \& Gaines, S. D. (2005). The dynamics of species invasions. In D. F. Sax, J. J. Stachowicz, \& S. D. Gaines (Eds.) Species invasions (pp. 447-465). Sunderland: Sinauer Associates.

Schall, J. J. (1977). Thermal ecology of five sympatric species of Cnemidophorus (Sauria: Teiidae). Herpetologica, 33, 261-272.

Schmidt-Kittler, N. (Ed.). (1987). European reference levels and correlation tables. Münchner Geowissenschafliche Abhandlungen (A), 10, $15-31$.

Sclater, J. G., Hellinger, S., \& Tapscott, C. (1977). Paleobathymetry of Atlantic Ocean from Jurassic to present. Journal of Geology, 85, 509-552.

Scotese, C.R. (2004). Cenozoic and Mesozoic paleogeography: changing terrestrial biogeographic pathways. In M.V. Lomolino, \& L.R. Heaney, L.R (Eds.) Frontiers of biogeography (pp. 9-26). Sunderlans: Sinauer Associates.

Scotland, R. W., Olmstead, R. G., \& Bennett, J. R. (2003). Phylogeny reconstruction: the role of morphology. Systematic Biology, 52, $539-548$.

Sepkoski, J. J. (1996). Competition in macroevolution: the double wedge revisited. In D. Jablonsky, D. Erwin, J. Lipps (Eds.) Evolutionary Paleobiology. Chicago: University of Chicago Press, 211-255.

Simberloff, D. S. (1981). Community effects of introduced species. In M. H. Nitecki (Ed.) Biotic crises in ecological and evolutionary time (pp. 53-81). New York: Academic Press.

Simpson, G. G. (1940). Mammals and land bridges. Journal of the Washington Academy of Sciences, 30(4), 137-163.

Simpson, G. G. (1980). Splendid isolation: the curious history of mammals in South America. New Haven: CT, Yale University Press.

Smith, K. T. (2009a). Eocene lizards of the clade Geiseltaliellus from Messel and Geiseltal, Germany, and the early radiation of Iguanidae (Reptilia: Squamata). Bulletin of the Peabody Museum of Natural History, 50(2), 219-306.

Smith, K. T. (2009b). A new lizard assemblage from the earliest Eocene (Zone WAO) of the Bighorn Basin, Wyoming, USA: biogeography during the warmest interval of the Cenozoic. Journal of Systematic Palaeontology, 7(3), 299-358.

Smith, K. T. (2011). The evolution of mid-latitude faunas during the Eocene: Late Eocene lizards of the medicine Pole Hills reconsidered. Bulletin of the Peabody Museum of Natural History, 52(1), 3-105.

Smith, K. T., \& Gauthier, J. A. (2013). Early Eocene lizards of the Wasatch Formation near Bitter Creek Wyoming: diversity and paleoenvironment during an interval of global warming. Bulletin of the Peabody Museum of Natural History, 54(2), 135-230.

Smith, T., Rose, K. D., \& Gingerich, P. (2006). Rapid Asia-Europe-North America geographic dispersal of earliest Eocene primate Teilhardina during the Paleocene-Eocene thermal maximum. PNAS, 103(30), $11223-11227$.

Smith, T., Quesnel, F., De Ploëg, G., De Franceschi, D., Métais, G., De Bast, E., Solé, F., Folie, A., Boura, A., Claude, J., Dupuis, C., Gagnaison, C., Iakovleva, A., Martin, J., Maubert, F., Prieur, J., Roche, E., Storme, J.-Y., Thomas, R., Tong, H., Yans, J., \& Buffetaut, E. (2014). First Clarkforkian equivalent land mammal age in the latest Paleocene basal Sparnacian Facies of Europe: Fauna, Flora, Paleoenvironment and (bio)stratigraphy. PLoS One, 9(1), e86229. https://doi.org/10.1371/journal.pone.0086229.

Springer, M. S., Meredith, R. W., Janecka, J. E., \& Murphy, W. J. (2011). The historical biogeography of mammals. Philosophial Transaction Royal Society B, 366, 2478-2502.

Stehli, F. G., \& Webbs, S. D. (Eds.). (1985). The great American biotic interchange. Plenum Press: New York.

Stehlin, H. G. (1909). Remarques sur les faunules de mammifères des couches éocènes et oligocènes du Bassin de Paris. Bulletin Société Géologique de France, 4(9), 488-520. 
Storch, G. (1981). Eurotamandua joresi, ein Myrmecophagidae aus dem Eozän der Grube Messel bei Darmstadt (Mammalia, Xenarthra)? Senckenbergiana lethaea, 61, 247-289.

Storch, G., \& Habersetzer, J. (1991). Rückverlagerte Choanen und akzessorische Bulla tympanica bei rezenten Vermilingua und Eurotamandua aus dem Eozän von Messel (Mammalia, Xenarthra). Zeitschrift Säugetierkunde, 56, 257-271.

Stramma, L., \& Peterson, R. G. (1990). The South Atlantic current. Journal of Physical Oceanography, 20, 846-859.

Sulimski, A. (1975). Results of the Polish-Mongolian paleontological expeditions. Part VI. Macrocephalosauridae and Polyglyphanodontidae (Sauria) from the Late Cretaceous of Mongolia. Paleontologia Polonica, 33, 25-102.

Tilman, D. (2004). A stochastic theory of resource competition, community assembly and invasions. PNAS, 101, 10854-10861.

Tilman, D., May, R. M., Lehman, C. L., \& Nowak, M. A. (1996). Habitat destruction and the extinction debt. Nature, 371, 65-66.

Tucker, D. B., Colli, G. R., Giugliano, L. G., Hedges, S. B., Hendry, C. R., Lemmon, E. M., Lemmon, A. R., Sites, J. W., \& Pyron, R. A. (2016). Methodological congruence in phylogenomic analyses with morphological support for teiid lizards (Sauria: Teiidae). Molecular Phylogenetics and Evolution, 103, 75-84.

Venczel, M., \& Codrea, V. A. (2016). A new teiid lizard from the Late Cretaceous of the Hateg Basin, Romania and its phylogenetic and palaeobiogeographical relationships. Journal of Systematic Palaeontology, 14, 219-237.

Verluys, J. (1910). Streptostylie bei Dinosaurien, nebst Bemerkungen über die Verwandschaft der Vögel und Dinosaurier. Zoologische Jahrbücher, 30, 75-260.

Vermeij, G. J. (1991). When biotas meet: understanding biotic interchange. Science, 253, 1099-1104.

Vermeij, G. J. (2005). Invasion as expectation. In D. Sax, J. J. Stachowicz, \& S. D. Gaines (Eds.) Species invasions, insights into ecology, evolution and biogeography (pp. 315-339). Sunderland: Sinauer Associates.

Vianna, M. L., \& Menezes, V. V. (2011). Double celled subtropical gyre in the South Atlantic Ocean: Means, trends, and interannual changes. Journal of Geophysical Research, 116. https://doi.org/10.1029/ 2010JC006574.

Vidal, N., \& Hedges, B. S. (2005). The phylogeny of squamate reptiles (lizards, snakes, and amphisbaenians) inferred from nine nuclear protein-coding genes. Comptes Rendus Biologies, 328, 1000-1008.

Vidal, N., Azvolinsky, A., Cruaud, C., \& Hedges, B. (2008). Origin of tropical American burrowing reptiles by transatlantic rafting. Biological Letters, 4, 115-118.

Villa, A., Abella, J., Alba, D. M., Almécija, S., Bolet, A., Koufos, G. D., Knoll, F., Luján, A. H., Morales, J., Robles, J. M., Sánchez, I., \&
Delfino, M. (2018a). Revision of Varanus marathonensis (Squamata Varanidae) based on historical and new material: morphology, systematics, and paleobiogeography of the European monitor lizards. PLoS One, 13(2),e0207719. https://doi.org/10.1371/journal.pone. 0207719.

Villa, A., Kirchner, M., Alba, D. M., Bernardini, F., Bolet, A., Luján, A. H., Fortuny, J., Hipsley, C. A., Müller, J., Sindaco, R., Tuniz, C., \& Delfino, M. (2018b). Comparative cranial osteology of Blanus (Squamata: Amphisbaenia). Zoological Journal of the Linnean Society, $X X, 1-24$.

Vitt, L. J., \& Pianka, E.R. (2004). Historical patterns in lizard ecology: what teiids can tell us about lacertids. In V. Pérez-Mellado, N. Riera, A. Perera (Eds.) The Biology of Lacertid lizards. Evolutionary and Ecological Perspectives (pp. 139-157). Menorca: Institut Menorquí d'Estudis. Recerca 8 pp.

Webb, S. D. (1991). Ecogeography and the great American interchange. Paleobiology, 17, 266-280.

Wiens, J. J., Hutter, C. R., Mulcahy, D. G., Noonan, B. P., Townsend, T. M., Sites, J. W., \& Reeder, T. W. (2012). Resolving the phylogeny of lizards and snakes (Squamata) with extensive sampling of genes and species. Biology Letters, 8, 1043-1046.

Wiser, S. K., Allen, R. B., Clinton, P. W., \& Platt, K. H. (1998), Community structure and forest invasion by an exotic herb over 23 years. Ecology, 79, 2071-2081.

Woodruff, D. S., \& Mulvey, M. (1997). Neotropical schistosomiasis: African affinities of the host snail Biomphalaria glabrata (Gastropoda: Planorbidae). Biological Journal of the Linnean Society, 60, 505-516.

Yoder, A. D. (1996). The use of phylogeny for reconstructing lemuriform biogeography. In W. R. Lourenço (Ed.) Biogéographie de Madagascar (pp. 245-258). Paris: Editions de l'ORSTOM.

Yoder, A. D., Burns, M. M., Zehr, S., Delefosse, T., Veron, G., Goodman, S., \& Flynn, J. J. (2003). Single origin of Malagasy Carnivora from an African ancestor. Nature, 421, 734-737.

Zachos, J., Pagani, M., Sloan, L., Thomas, E., \& Billups, K. (2001). Trends, rhythms, and aberrations in global climate 65 Ma to present. Science, 292, 686-693.

Zaher, H., \& Rieppel, O. (1999). Tooth implantation and replacement in Squamates, with special reference to Mosasaur lizards and snakes. American Museum Novitates, 3271, 1-19.

Zug, G. R. (1993). Herpetology, an introductory biology of amphibians and reptiles (527p). Cambridge: Academic Press.

Publisher's note Springer Nature remains neutral with regard to jurisdictional claims in published maps and institutional affiliations. 